\title{
A!
}

This is an electronic reprint of the original article.

This reprint may differ from the original in pagination and typographic detail.

Shulist, Patrick; Kistruck, Geoffrey M.

\section{Linking Management Theory with Poverty Alleviation Efforts Through Market Orchestration}

Published in:

Journal of Business Ethics

DOI:

10.1007/s10551-020-04533-1

Published: 01/10/2021

Document Version

Early version, also known as pre-print

Published under the following license:

Unspecified

Please cite the original version:

Shulist, P., \& Kistruck, G. M. (2021). Linking Management Theory with Poverty Alleviation Efforts Through Market Orchestration. Journal of Business Ethics , 173(2), 423-446. https://doi.org/10.1007/s10551-020-04533-1

This material is protected by copyright and other intellectual property rights, and duplication or sale of all or part of any of the repository collections is not permitted, except that material may be duplicated by you for your research use or educational purposes in electronic or print form. You must obtain permission for any other use. Electronic or print copies may not be offered, whether for sale or otherwise to anyone who is not an authorised user. 


\title{
LINKING MANAGEMENT THEORY WITH POVERTY ALLEVIATION EFFORTS THROUGH MARKET ORCHESTRATION
}

\author{
GEOFFREY M. KISTRUCK \\ York University \\ Schulich School of Business \\ 4700 Keele Street \\ Toronto, ON M3J 1P3 \\ Tel: +1 (416) 736-2100 \\ Email: gkistruck@schulich.yorku.ca \\ PATRICK SHULIST \\ Aalto University Business School \\ P.O. Box 11000 (Otakaari 24) \\ FI-00076, Aalto \\ Tel: +358505146067 \\ Email: patrick.shulist@aalto.fi
}

Running Title: Linking Management Theory with Poverty Efforts

The authors declare that they have no conflict of interest. We also acknowledge the financial support of the Social Sciences and Humanities Research Council of Canada Partnership Development Grant (grant \# 890-2014-0059) for making this research possible. 


\begin{abstract}
Top-tier management journals are advocating for greater relevance from management research to Grand Challenges such as poverty alleviation. However, many scholars struggle to identify linkages between the practical undertaking of poverty alleviation and theory development opportunities in the management literature. Responding to this call, we develop and outline a framework for theorizing from an increasingly common business-based poverty alleviation approach known as 'market orchestration.' Core to this framework are a set of contextual difference that contrast with the Western environment in which most management theorizing has taken place. These contextual differences - at the micro, meso, and macro levels challenge the implicit assumptions underpinning much of the management literature. As a result, a substantial opportunity exists to identify new predictors, contingencies, explanations, and outcomes that can significantly inform theory. Equally important, by focusing on the contextual differences and the challenges they create, management scholars can provide practical guidance to organizations engaged in market orchestration efforts.
\end{abstract}




\section{INTRODUCTION}

Over the past decade, management scholars have shown heightened enthusiasm for research addressing pressing societal challenges (Banks et al., 2016; George, Howard-Grenville, Joshi, \& Tihanyi, 2016). Such aspirations are reflected in multiple themes for the Academy of Management's Annual Conference (e.g. Dare to Care in 2010, Making Organizations Meaningful in 2016, Improving Lives in 2018; Academy of Management 2010, 2016, 2018), as well as special issues in top management journals (e.g. Academy of Management Journal, 'Grand Challenges'; Academy of Management Review, 'Understanding and Creating Caring and Compassionate Organizations'; Journal of Management Studies, 'Social and Economic Inequality'). While there is no shortage of societal problems needing scholarly attention, the recent shift in practices aimed at reducing global poverty has created a significant opportunity for the field of management to contribute to such efforts (Bruton, Ketchen, \& Ireland, 2013; Saebi, Foss, \& Linder, 2019).

For many years, approaches to poverty alleviation were predominately focused on structuring more equitable international trade agreements (Morgan, Power, \& Weigel, 1993), improving government capacity (Andrews, Pritchett, \& Woolcock, 2017), and providing direct aid to address issues related to gender, health, and social exclusion (Brass, Longhofer, Robinson, \& Schnable, 2018; Vo \& Van, 2019). As such, the topic of poverty fell primarily under the academic purview of economists, political scientists, and sociologists. However, development actors are increasingly pursuing a more 'business-oriented' approach to alleviating poverty (Bruton et al., 2013; Cooney \& Shanks, 2010; Mair, Martí, \& Ventresca, 2012) that involves; (1) identifying new profitable business opportunities, (2) organizing new business groups, (3) training in new business practices, and (4) facilitating new market linkages between businesses. 
This new approach of 'market orchestration' seeks to re-organize the microstructures of local markets to achieve improved and more sustainable financial and social benefits for impoverished persons. Such an approach typically involves interventions aimed at orchestrating new business arrangements so that those living in poverty can achieve increased profits from the sale of goods and services to local or international markets (Parmigiani \& Rivera-Santos, 2015). Additionally, market orchestration can also involve finding new ways to design and deliver socially-valuable products and services to impoverished communities (Prahalad, 2005). Thus, the market orchestration approach seemingly aligns with theories in entrepreneurship, organizational behavior, and strategy, and as a result, presents an opportunity for management scholars to contribute knowledge to such poverty alleviation efforts.

However, many management scholars with a passion for alleviating poverty struggle to recognize how market orchestration - as a phenomenon - presents consummate opportunities for theorizing. As a result, they face difficulty in seeing opportunities to 'publish their passion' within mainstream management journals. To help elucidate such opportunities, we set the stage by first deconstructing the process of market orchestration into four key components that are naturally linked to mainstream management literatures. Next, we introduce the core pivot of our paper: contextual differences. Contextual differences represent what is unique about the phenomenon of market orchestration, and why it is replete with theory building opportunities (George, Corbishley, Khayesi, Haas, \& Tihanyi, 2016). For instance, short-term cognitive temporal orientations, high levels of resource scarcity, and the overlapping of social and economic spheres all serve to challenge implicit assumptions of management theory. We then present extensive examples of how such contextual differences can be leveraged to build new theory at the micro, meso, and macro levels. Thus, we offer a framework that highlights specific 
research questions and topics that management scholars can use for conducting theoretically rigorous research on the topic of poverty alleviation. Moreover, developing this theory can help answer pressing calls to enhance the practice of market orchestration interventions, many of which have unfortunately faced significant challenges (Karlan \& Appel, 2016)

\section{ALTERNATIVE APPROACHES TO POVERTY ALLEVIATION}

Poverty is a persistent and endemic challenge in all countries, but particularly in regions through Africa, Latin America, and parts of Asia (Zoogah, Peng, \& Woldu, 2015.More specifically, poverty is most concentrated in the world's developing countries, wherein an estimated 783 million people live on less than $\$ 1.90$ per day (World Bank, 2018).

Multidimensional measures tell a similar story about the concentration of poverty within developing countries (Alkire, Roche, \& Vaz, 2017), as do capability-based views (Hulme \& Shepherd, 2003; Sen, 2001), though there can still be meaningful disconnects between economic and social measures of poverty (Asadullah, Savoia, \& Mahmud, 2014). Accordingly, developing countries have long been the focus of poverty alleviation efforts by multilateral institutions (e.g. World Bank), non-governmental organizations (NGOs), and private enterprise - collectively, development actors.

Efforts to alleviate poverty take varied approaches depending on how a particular development actor views the underlying causes of poverty. Many development actors see poverty as a systemic problem; to alleviate it, the overall system much change. For instance, many developing country governments and NGOs see poverty as the result of an exploitative international trade system that disadvantages poorer countries even after the end of the colonial era (Handelman \& Brynen, 2019). As such, these actors may work to change the overarching 'rules of the game' so that developing countries can benefit from international trade rather than 
be held back by it (Morgan et al., 1993). Other development actors such as the World Bank and the International Monetary Fund, tend to view poverty as a result of inefficient institutions and poor infrastructure (Handelman \& Brynen, 2019). As a result, such development actors typically focus their efforts on the taxation and monetary policies of developing countries (Oberdabernig, 2013), as well as on the building of electrical grids, roads, and telecommunication networks (Fedderke, Perkins, \& Luiz, 2006). Strong emphasis is also placed on the buildings of local state capacity (Andrews et al., 2017), as corruption ${ }^{1}$ and a lack of administrative aptitude are expected to dampen the effects of even the best designed economic program or infrastructure package (Torres-Rojo, Moreno-Sánchez, \& Amador-Callejas, 2019).

Another prevalent view of poverty is that it is a 'trap' (Haider, Boonstra, Peterson, \& Schlüter, 2018); once people fall below a certain asset level, encounter significant health challenges, or miss out on early educational opportunities, they enter a cycle whereby today's deprivation is the cause of tomorrow's deprivation (Giesbert \& Schindler, 2012). Recognizing this, many development actors pursue programs aimed at giving beneficiaries a 'push' out of poverty traps - often by way of the transfer of cash or some other productive asset to those 'stuck' in poverty (Asadullah \& Ara, 2016). To provide a protective backstop against the impact of poverty traps, development actors also implement free or low-cost programs to address disease, malnutrition, and homelessness (Brass et al., 2018; Vo \& Van, 2019). Relatedly, other poverty-alleviation interventions use a more 'promotional' approach that seeks to help those vulnerable to poverty traps from sliding into them in the first place (Larsen \& Lilleør, 2014).

\section{A 'Market Orchestration' Approach to Poverty Alleviation}

\footnotetext{
${ }^{1}$ Although research has shown that illicit financial outflows due to secrecy in the global financial system is often an even greater challenge than corruption (Baker, 2005).
} 
While such prominent approaches to alleviating poverty have shown success (Asadullah \& Savoia, 2018), these programs have important shortcomings in delivering sustainable improvement in the lives of the poor (Easterly, 2006; Moyo, 2009). For instance, limitations in state capacity have hindered program implementation (Harman \& Williams, 2014), while decades of interventions have fostered a marked sense of dependency in many contexts (Ouattara, 2007). As a result, a new more market oriented approach leveraging business as a tool for poverty alleviation has emerged (Bruton et al., 2013; Cooney \& Shanks, 2010).

This approach - which we refer to as 'market orchestration' - is focused on building or improving direct trade linkages between impoverished persons and external buyers/suppliers. Much like the above-mentioned systemic approaches to addressing poverty, market-orchestration involves creating the necessary infrastructure and institutions to facilitate more efficient financial transactions - but for a particular industry and a particular community rather than for the country as a whole. And much like the promotional approach discussed previously, market-orchestration involves building individual and group capacity - but again focused on industry-specific skills for a small sub-set of individuals rather than general human capital. Thus, such an approach is focused on building 'market microstructures' (Spulber, 1996); the holistic set of cognitive, network, and institutional components necessary for successful business operations at a local scale (Mair, Wolf, \& Seelos, 2016; Sutter, Webb, Kistruck, Jr, \& Ireland, 2017).

Typically, an NGO or 'social entrepreneur' acts as the primary orchestrator of such market-building efforts (Kistruck, Beamish, Qureshi, \& Sutter, 2013). However, such initiatives often involve for-profit and multinational corporations as key transactional partners, as well as the support of local or regional governments (Webb, Kistruck, Ireland, \& Ketchen, Jr., 2010). We have elected to focus on the perspective of the NGO or social entrepreneur to simplify the 
illustration of primary linkages between market orchestration and existing management theory. However, there are undoubtedly alternative linkages that could be drawn by taking other actors' perspectives, and by investigating the dynamics of having multiple orchestrators.

To illustrate an 'upstream' market orchestration approach, consider the efforts of the Brazilian-based Odebrecht Foundation in the Bahia region where many farmers grew palm hearts but could get only low prices at local markets. The Odebrecht Foundation, acting as the primary market orchestrator, discovered through active search that some neighboring countries actually viewed palm hearts as a delicacy and were willing to pay a premium. Recognizing this, the project began by aggregating farmers into cooperatives, and training them on the best practices for producing, processing, and packaging high quality palm hearts. Odebrecht then worked to link the groups with large buyers in neighboring countries, and to negotiate forward contracts at favorable prices. In these ways, Odebrecht did not itself produce, buy or sell palm hearts, but instead served to orchestrate such a market.

Market orchestration can also occur in a more 'downstream' fashion by bringing new products or services to impoverished (and often rural) communities, which is a core goal of the social business approach championed by Prahalad (2005) and Yunus (2010). Prior work within the field of management has sometimes referred to this as 'inclusive' or 'frugal' innovation within base-of-the-pyramid markets (Basu, Banerjee, \& Sweeny, 2013; George, McGahan, \& Prabhu, 2012; Hart \& Christensen, 2002) whereby more affordable products or services become accessible to previously disenfranchised populations. For example, CARE Ghana launched a market orchestration initiative in the northern part of the country to design and bring a new infant nutritional supplement to rural communities. First, CARE recognized the opportunity to introduce the supplement, and worked with a local University and Ajinomoto (the Japanese food 
conglomerate) to formulate an effective, yet affordable, supplement. Second, they worked to facilitate new transactional linkages by recruiting a local production company and coordinating supply hubs. Third, CARE trained local entrepreneurs on the product's nutritional benefits, and on methods of encouraging new product adoption. Finally, CARE created community groups to support sales and nutrition education.

Much like there have been criticisms leveled at governance reforms and structural adjustment programs for attempting to infuse Western values into developing countries (Hoey, 2017), market orchestration can also be criticized for its rooting in Western-style capitalism. Moreover, market orchestration is imprinted with the exploitative history of markets in much of the developing world, as markets were used as a means of colonial exploitation (Meredith, 2011), something continued by a number of multinationals in the decades since (Baker, 2005). Moreover, the inherent power imbalances between development organizations and beneficiaries can lead to exploitation (Rugraff, Sánchez-Ancochea, \& Sumner, 2009). However, just because a system has been used exploitatively does not mean it is inherently exploitative.

A useful way of thinking about the ethics of market orchestration is in a comparative manner with other poverty alleviation approaches. In doing this, the question shifts from whether market orchestration is good or bad, to what is the right intervention for the situation. For instance, orchestrating income generating activities may decrease food security by shifting farmers away from subsistence agriculture. Yet, a traditional aid approach like food handouts also reduces the number of food producers in an area (Ferrière \& Suwa-Eisenmann, 2015) without the associated benefit of improving farmer incomes. Similarly, market orchestration may impose a Westernized view of markets, but it also actively works against instilling the sense of dependency that permeates many other development interventions (Moyo, 2009; Ouattara, 
2007). Along these lines, market orchestration may allow local participants greater flexibility and resilience, as market-based mechanisms give them the opportunity to adapt to their personal needs; a handout of a mosquito net can only be used for so many purposes, but the income from selling shea butter soap can be used to a multitude of ends.

In constructing our framework linking management theory with poverty alleviation efforts, we do not advocate market orchestration as a panacea for poverty, but instead assume that market orchestration can be beneficial at least in some circumstances. Of course, avoiding unintended consequence is imperative, as is ensuring that interventions are implemented effectively. In fact, we advocate for greater involvement by the management field specifically because our unique scholarly expertise can help design more effective market-orchestration programs that avoid unintended consequences, and thereby overcome some of the current challenges with intervention design (Karlan \& Appel, 2016).

\section{Key Components of a Market Orchestration Approach}

While there is undoubtedly a fair degree of variance in the types of market orchestration efforts undertaken by development actors, we have elected to focus on the four most common components shared across them. This list is not exhaustive, but broadly covers the core of most initiatives: (1) identification of new opportunities, (2) organization of new groups, (3) training in new practices, and (4) facilitating new transaction linkages.

\section{Identification of New Opportunities}

The process of market orchestration typically begins with an analysis of existing market arrangements, as well as local capabilities and needs. The goal is to identify opportunities for economic and social gain. In the upstream direction, common opportunities involve finding new buyers for agricultural products (i.e. grains, fruits) or livestock (i.e. cows. chickens) (Dawson, 
Martin, \& Sikor, 2016), or increasing production of cash crops (e.g. coffee, spices). Development organizations are also increasingly looking to identify non-agricultural income generating activities such as weaving and soap making to supplement agricultural incomes (Davis et al., 2010). Moreover, and especially in urban areas, some opportunity identification efforts focus on services rather than agricultural products, as these may be less volatile to changes in global climate (Hart, 2011). From a downstream direction, market orchestration opportunities involve the provision of affordable healthcare and hygiene products, such as low-cost contraceptives, private healthcare, and affordable drugs (Kolk, Rivera-Santos, \& Rufín, 2014). Nutrition opportunities are also commonly identified, and micro-electricity grids are increasingly being pursued.

In both the up- and downstream variants, the development organization often takes the lead in identifying new opportunities (Kistruck, Beamish, et al., 2013; Parmigiani \& RiveraSantos, 2015). However, increased emphasis is being placed on indigenous opportunity identification (Bullough, Renko, \& Myatt, 2014) whereby local actors identify new opportunities on their own. To help aid in this process, many development organizations are now offering entrepreneurship education programs as part of their efforts. (ILO, 2016).

\section{Organizing New Groups}

Most upstream market orchestration initiatives aggregate impoverished individuals into new groups of 10-30 individuals (Sutter et al., 2017). Creating groups facilitates economies of scale that allow local producers to; (1) engage directly with larger buyers who are reluctant to transact at an individual level, and (2) obtain production inputs at bulk discounted prices. Group benefits may also include labour pooling by women with household responsibilities, and knowledge sharing about best practices (Sutter, Kistruck, \& Morris, 2014). 
The most widespread form of downstream group formation is in microfinance. Here, newly formed groups receive loans based on collective guarantees that reduce risk (Banerjee, Karlan, \& Zinman, 2015). In addition, it is also common to form 'sales groups' where individuals work collectively to sell and distribute new products and services using a shared process. Group formation - of sorts - also occurs with healthcare insurance and with crop insurance, as sufficiently large groups are needed to make the products viable.

\section{Training in New Practices}

After group formation, market orchestration typically involves training beneficiaries in new practices. Upstream, these practices involve optimizing production, such as properly using fertilizers to improve agricultural yields place (Larsen \& Lilleør, 2014). However, entirely new sets of practices can be taught. Examples include fair trade certifications, and the use of new technical assets such as tractors, refrigeration systems, or quality testing equipment. Financial literacy training is also common (Kolk et al., 2014). Downstream, local salespeople are trained on product specifications, inventory control, financial management, and sales techniques (London, Esper, Grogan-Kaylor, \& Kistruck, 2014). Moreover, key community members (i.e. doctors, chiefs, etc.) may be taught the basic technical aspects of new products/services, so that these opinion leaders can help novel items receive broader acceptance.

\section{Facilitating New Transactional Linkages}

Almost all market orchestration initiatives involve creating new transactional linkages as part of economic/social value creation (Kistruck, Beamish, et al., 2013). This may involve new trade relationships to bypass existing intermediaries (Sutter et al., 2017), or creating connections with entirely new markets. Facilitating these linkages involves more than a simple verbal introduction (Parmigiani \& Rivera-Santos, 2015). Especially at the early stages of new trading 
relationships, there is assistance with legal contracting, logistics, and even financial guarantees (Kistruck, Beamish, et al., 2013). New transactional linkages can also be formed between producers and new input suppliers providing cheaper or better input materials. Moreover, development organizations link local beneficiaries not only with new buyers or suppliers, but also with a broader set of transaction supporting actors such as the government, industry partners, and other NGOs (Armanios, Eesley, Li, \& Eisenhardt, 2017; Dutt et al., 2016)

\section{CONTEXTUAL DIFFERENCES OF MARKET ORCHESTRATION}

While the four components of market orchestration share many broad similarities with mainstream management phenomena, the context in which such efforts take place differs significantly from those in which many management theories were formed. Thus, existing theories are broadly relevant, but are also imperfect due to key contextual differences originating at the micro, meso, and macro levels (please see Table 1). Indeed, recent work increasingly highlights the need to account for these contextual differences in theorizing (Baker \& Welter, 2018; Henrich, Heine, \& Norenzayan, 2010; Welter, Baker, \& Wirsching, 2019).

Insert Table 1 about here

\section{Micro Level}

We define micro-level contextual differences as those relating to individual cognition. Within market orchestration, theory is challenged because the cognitive patterns exhibited by beneficiaries of such initiatives often differ from what existing literature assumes. More specifically, beneficiaries of market orchestration initiatives often rely much more extensively on a highly routinized set of heuristics (Banerjee \& Duflo, 2011). The nature of life differs substantially between the context of market orchestration and the Western World. In rural areas, cognitive processes are usually geared towards the rhythms of farming, which has changed little 
for decades, despite the introduction of mechanization and modern techniques. In urban areas, cognitive processes are typically geared towards managing a chaotic atmosphere where formal authority has little power, and markets are organized through complex social settlements. These cognitive processes are consequential to market function. While such heuristics may be welldeveloped for managing certain aspects of daily life, but they are not necessarily helpful in the process of constructing new markets. As such, default behaviours exhibited in economic exchange can often be counterproductive (Banerjee \& Duflo, 2011), such as splitting up a day's earnings into two thirds for the business and one third for personal consumption. Similarly, a rule of selling all one's produce before returning home may not always be ideal as later sales may represent a significant economic loss (Viswanathan \& Rosa, 2007).

Market orchestration beneficiaries also tend to be communally oriented (Khayesi \& George, 2011). This orientation gives rise to prosocial behaviours and a tendency towards strong reciprocity. Moreover, decision-making may be less ego-centric and more focused on the good of the community. These factors alter the nature of social interactions in general, and economic exchange in particular (Ansari, Munir, \& Gregg, 2012; Kistruck, Beamish, et al., 2013).

\section{Meso Level}

Meso level elements are those dealing with the interrelationships between actors. Social networks within impoverished contexts are relied upon more heavily than in most Western contexts as; (1) they are necessary for mutual survival (Narayan \& Petesch, 2002) and, (2) family and social ties have not yet been rationalized away by markets and governments (e.g. unlike in the United States: Putnam, 1995). In general, social networks within impoverished contexts are more dense and overlapping, and social capital is heightened as a result (Viswanathan, 2013). This causes consequential differences relative to the Western context. For instance, in the 
Western World, many social network ties are only supportive of market transactions, rather than central and foundational to them as in the context of market orchestration (Narayan \& Petesch, 2002). Moreover, the structure and composition of social networks fundamentally differs from those typical of the Western World, which is consequential for any activity relying on social networks (Slade Shantz, Kistruck, \& Zietsma, 2018).

In the context of market exchange, traditional institutions also remain highly important. These include chieftaincies, farmers' groups, trading circles, self-help groups, and women's groups (Amoako \& Lyon, 2014; Narayan \& Petesch, 2002). We classify these institutions as meso-level since are sets of rules and norms held within localized social networks that vary between communities on the order of hundreds, or of thousands, rather than millions. There may be similarities in the enactment of these institutions across communities, but they can be, and are, customized at the local level. This implies an additional layer of difficulty is added to market exchange as contracting parties may try to act on mismatched or conflict norms and rules. Moreover, the institutions within a community may clash (Mair et al., 2012), causing challenges for even local exchange, as the negotiated settlement of which rules and norms to abide by can change with power structures in the community (Lazzarini, Miller, \& Zenger, 2004).

\section{Macro Level}

Macro-level elements are those relating to country-level factors. The contexts in which market orchestration efforts occur often have significant infrastructure challenges (Webb et al., 2010), information scarcity (Slade Shantz et al., 2018), and instability (Bullough et al., 2014) as compared to traditionally studied contexts. Additionally, market orchestration contexts are often characterized by weak formal institutions, which are replaced by a mixture of informal institutions (Mair et al., 2012) that require granular consideration when constructing supply 
chains (Parmigiani \& Rivera-Santos, 2015). This changes the nature of market exchange in several ways. First, the universalistic rules and norms that market participants in the West take for granted may not be present (North, 1990). These norms and rules fundamentally underpin market exchange, so their absence is necessarily consequential to theory. Second, informal institutions may differentially repress certain functions of formal institutions, leading to situations of institutional polycentricity where multiple strong institutions demand contradictory action (Sutter, Webb, Kistruck, \& Bailey, 2013).

\section{LINKING CONTEXTUAL DIFFERENCES WITH GAPS IN MANAGEMENT THEORY}

As we have attempted to highlight, the process of market orchestration shares many similarities to mainstream management phenomena, and yet also many important contextual differences. This 'similar yet different' constitution presents a prolific opportunity for management scholars to explore well-established theoretical relationships (i.e. agency theory, institutional theory, transaction cost economics) under boundary conditions where traditional underlying assumption may be significantly challenged (Bruton et al., 2013; George, Corbishley, et al., 2016; Walsh, 2015). Doing so is especially important for avoiding the parochial imposition of Western assumptions into other contexts (Boyacigiller \& Adler, 1991; Henrich et al., 2010). ${ }^{2}$

Building on existing arguments (Barnard, Cuervo-Cazurra, \& Manning, 2017; George, Corbishley, et al., 2016) we highlight four distinct avenues for developing theory from the study of market orchestration. First, and most widely discussed, is the addition of new contingencies to existing theory by the identification of moderators (instances where established theoretical relationships vary based on context). For instance, in their study of cooperative vs. competitive

\footnotetext{
${ }^{2}$ While we certainly acknowledge that the phenomenon of 'market orchestration' also provides opportunities for grounded theory and indigenous theorizing as alternative paths for contributing to theory, we focus on the contextualization of existing theories as one potential avenue for building theory.
} 
goal structuring in Sri Lanka, Kistruck et al. (2016) hypothesize and test how extreme resource scarcity alters existing predictions from social interdependence theory. Second, scholars can identify new explanations, or mediators, for why established relationships between two variables/constructs exist. For example, Slade Shantz, Kistruck, Pacheo, and Webb (2019), in their study of newly formed Ghanaian cooperatives, uncover the important mediating role of collective psychological ownership as a previously unaddressed link between the choice of organizational structure and intra-group conflict. Third, new predictors (e.g. independent variables) can be isolated for use within a theory. London et al. (2014) did this in their study of an eyeglasses distribution project in India by integrating three dimensions of poverty (economic, capability, and relational) into consumer behaviour theory to predict purchasing decisions. And finally, new outcomes (e.g. dependent variables) for a theory can be identified, such as when Sutter et al. (2013) identified a new typology of responses that entrepreneurs have to institutional pressures emerging from rarely studied 'illegitimate actors' in Guatemala City. All four types of theorizing are viable through both quantitative and qualitative empirical approaches.

Insert Tables $2 \& 3$ about here

We turn now to explicitly linking the salient contextual elements of market orchestration to potential gaps in management theory. For each of the four sub-components of market orchestration, we first describe linkages to mainstream management literatures. Subsequently, we highlight prior studies that have successfully built theory from the practice of market orchestration, and then detail potential research questions for future study as a result of contextual differences associated with market orchestration. Table 2 provides additional 
examples of theoretical opportunities organized by initiative component/contextual difference, while Table 3 provides further opportunities for contributing to management theories.

In presenting our examples we necessarily focus separately on subcomponents of the complex phenomenon of market orchestration. Indeed, market orchestration often involves setting up entirely new markets (Lindeman, 2014), aligning the interests of varied stakeholders over an extended period of time (Mason \& Chakrabarti, 2017), or working towards superordinate goals such as sustainability (Onyas, McEachern, \& Ryan, 2018; Onyas \& Ryan, 2015). This complexity certainly needs to be considered during the practical orchestrating of markets. However, our examples purposefully focus on more discrete and tractable problems as a means of illustrating directly linkages between the subcomponents of the phenomenon of marketorchestration with specific theoretical lenses.

\section{Identification of New Opportunities}

There are natural links between the identification of new market opportunities and the entrepreneurship literature. Indeed, there are many similarities between the typical process employed in the identification of new opportunities for market orchestration initiatives (opportunity recognition, opportunity exploitation, etc.) and that of Kirzner's (1985) wellresearched process of entrepreneurship. However, much of the existing entrepreneurship literature makes assumptions which are significantly challenged within the context of market orchestration. For example, a proto-typical 'entrepreneur' within the entrepreneurship literature is often seen as someone who is growth-oriented, risk-taking, exhibits a high degree of locus of control, and motivated by personal gain (Chen, Greene, \& Crick, 1998; Palich \& Bagby, 1995). Comparatively, the beneficiaries acting as entrepreneurs within market orchestration activities are often subsistence-oriented, risk-averse, fatalistic in orientation, and motivated by community 
objectives (Bruton et al., 2013; Slade Shantz et al., 2018). While there have certainly been increased efforts to push the boundaries of such underlying assumptions through the study of social entrepreneurship (Mair \& Martí, 2006), informal entrepreneurship (Autio \& Fu, 2015), necessity entrepreneurship (Dencker, Bacq, Gruber, \& Haas, 2019), and indigenous entrepreneurship (Dana \& Anderson, 2007), the process of opportunity identification in the context of market orchestration provides unique possibilities for contributing to theory.

Several recent studies have already begun to leverage such possibilities. For example, Bradley et al.'s (2012) study of a market orchestration program in Kenya explores the factors that influence the success of new entrepreneurs. While prior theory would assume that financial, social, and human capital are important predictors of success, their study highlights the critical mediating role of 'innovation'. In other words, they find that in the absence of innovation as a mediator, traditional predictors are likely to lead to poor performance as the capital is deployed to primarily imitate existing ventures. Alvarez and Barney (2014) similarly theorize how it is only certain types of opportunities that lead to sustainable development, and leverage the context of market orchestration to contribute to the 'discovery vs. creation' debate taking place within the entrepreneurship field.

However, there are a number of additional avenues for future research to contribute meaningfully to theory. At a basic level, what modifications to existing constructs such as entrepreneurial self-efficacy (Chen et al., 1998) and entrepreneurial orientation (Lumpkin \& Dess, 1996), and their linkages to opportunity identification are required when the attributes of entrepreneurs differ significantly from existing theorizing? And what can be learned about what constitutes an 'entrepreneurial opportunity' with regards to market orchestration? A debate within the entrepreneurship field continues with respect to the appropriate formative and 
reflective indicators (i.e. innovativeness, exploitability, profitability, etc.) that constitute an 'opportunity', and further research on market orchestration with its differing actors and set of objectives may help clarify (or confound) such discussions.

There are also a number of specific research opportunities for potential theoretical contributions at the micro level (Table 1). For example, the entrepreneurs participating in market orchestration initiatives tend to rely extensively on heuristics (Sutter et al., 2017). As behavioural scientists have recently pointed out (Mullainathan \& Shafir, 2013), individuals living in poverty can often develop a 'scarcity mindset' that actually taxes mental bandwidth, and can lead to significant reductions in attention, accuracy, and cognitive control. Given that the process of identifying new market opportunities is inherently a cognitive process, what are the potential implications of a 'scarcity mindset' on the number and types of opportunities entrepreneurs living in poverty are able to evoke? And even more importantly, how can potential cognitive barriers to ideation of new opportunities be overcome? In other words, what is the relative efficacy of existing pedagogical approaches to 'teaching' opportunity identification capabilities (Martin, McNally, \& Kay, 2013) within market orchestration initiatives $?^{3}$ The context of market orchestration also provides a rich opportunity to further bridge newly emerging literature on resource-constrained cognition and associated cognitive biases with that of opportunity identification. For instance, what role do potential cognitive barriers play in the relative efficacy of 'causation' vs. 'effectuation' (Sarasvathy, 2001) approaches to opportunity discovery? And how do extreme levels of short-term orientation that are prevalent within the context of market

\footnotetext{
${ }^{3}$ We recognize that teaching such capabilities overlap with the category of "Training in New Practices" but have elected to discuss at this point given its topical relation to opportunity identification as a type of capability
} 
orchestration (Banerjee \& Duflo, 2011) impact the opportunity identification process and its outcomes?

Also at a micro level market, market orchestration initiatives often involve much less agency on the part of the entrepreneur than traditionally theorized within the opportunity identification process (Slade Shantz et al., 2018). While traditional entrepreneurship literature typically views opportunity identification as an individual act on the part of an 'alert' entrepreneur (Gaglio \& Katz, 2001), the process is much more complex in the context of market orchestration. For one, the act of opportunity identification for a given initiative is often done on the part of a third-party intermediary (i.e. NGO, Association, etc.) ${ }^{4}$ rather than the entrepreneur themselves (Sutter et al., 2017). How then does the involvement of such 'opportunity intermediaries' alter the opportunity identification process? What new predictors or mediators are at play when there is essentially a two-stage process where the 'opportunity' is first identified by one actor, and subsequently re-identified (or modified) by the entrepreneur themselves? And what are the implications for attribution theory in the context of opportunity identification and evaluation when ultimate success or failure is partially ascribed to someone other than the entrepreneur (Fiske \& Taylor, 1991)? The involvement of a third-party intermediary is not necessarily exclusive to market orchestration - indeed many governments, industry associations, consultants, etc. play a key role in the opportunity identification process within more traditional settings - and yet such involvement is largely underexplored from a theoretical basis.

Considering the meso level, there are differences in identity structures amongst entrepreneurs participating in market orchestration initiatives. According to identity theory

\footnotetext{
${ }^{4}$ For a critical perspective on oft misguided development see Sörensen (2010), Rugraff, Sánchez-Ancochea, Sumner (2009), Veltmeyer (2011), and Moyo (2009).
} 
(Stryker \& Burke, 2000), individuals are thought to possess multiple identities that are 'activated' at different times by various internal and external cues. Thus, different identities (i.e. mother, teacher, entrepreneur) are thought to be more or less salient at any given point in time, with only a single identity being prominent at any given point in time in order to avoid psychological distress (Kreiner, Hollensbe, \& Sheep, 2009). However, as compared to traditional contexts where entrepreneurs are often able to compartmentalize their various identities (i.e. having one identity at work, and another identity at home), contexts of market orchestration often entail an unavoidable 'blending' of identities due to the dense nature of their social networks. How does such 'identity blending' affect the types of opportunities that entrepreneurs identify? And how does it affect the types of opportunities entrepreneurs are willing to act upon? The answers to such questions can serve to not only inform entrepreneurship literature, but also identity theory more broadly which is still in the early stages of understanding how individuals react to the merging of identities (Ramarajan \& Reid, 2013).

And finally, at the macro level, the instability of the environment in which market orchestration initiatives occur results in several unexpected outcomes as compared to existing theoretical predictions. For example, the opportunity identification process is often portrayed as one in which there are a number of potential opportunities identified, and subsequently a single opportunity is selected (Shane \& Venkataraman, 2000). However, the high levels of uncertainty (price, environment, etc.) that characterize market orchestration contexts often leads to the simultaneous pursuit of multiple opportunities at founding - a 'born diversified' so to speak. Much as new research on 'born globals' (Knight \& Cavusgil, 2004) led to a rethinking of traditional theories of internationalization, the phenomenon of 'born diversified' can similarly alter our understanding of the ordering and sequencing of the entrepreneurship process. In 
another vein, the nature of the environment in which market orchestration takes place can also alter the ways in which entrepreneurs perceive potential opportunities. Within the entrepreneurship literature, the 'market' is often seen as constantly shifting with respect to technologies, customer preferences, etc. (Shane \& Venkataraman, 2000). As a result, opportunities are thought to arise by way of entrepreneurs 'connecting the dots' that are appearing and disappearing over time (Baron, 2006). However, what happens when the 'dots' are largely constant? The markets in which impoverished entrepreneurs operate often do not fundamentally change from a technological perspective, do not efficiently emit signals, and as a result have a limited number of 'dots' (Gras, Kistruck, Neda, \& Bruton, 2018). How do varying levels of market dynamism impact the way in which entrepreneurs perceive opportunities? More specifically, how does the process of opportunity identification change (i.e. stages, sources of input, etc.) when market signals are extremely weak?

\section{Organizing New Groups}

The second component of market orchestration is aggregating individuals into groups. This has natural linkages with existing management literature on organizational and group behavior, with corresponding theories rooted in social psychology, behavioral economics, and other disciplines (Brief \& Weiss, 2002). The focus of such literature is very much on issues of efficiency, power, status, and conflict - in other words, explaining and predicting potential downfalls (and advantages) of individuals acting collectively rather than in isolation (Bendersky \& Hays, 2012).

There are several characteristics of market orchestration that push the boundaries of existing theory with respect to group behavior. First, as compared to much of the existing literature that studies groups in a relatively isolated fashion - focusing on the structures, goals, 
and power differences within a single given group - members of a market orchestration group are often simultaneous participants in multiple groups (Sutter et al., 2017). Communities in which market orchestration efforts take place are described as 'island networks' (Slade Shantz et al., 2018) given their rural and often segregated nature from other communities which results in a highly dense set of intra-community ties. Furthermore, informal power structures within such communities are often much more salient in governing inter-personal interactions than in traditionally studied contexts (Webb et al., 2010). Such strong overlaps in both formal and informal social structures provide a number of opportunities for contributing to theory.

For example, a recent study by Slade Shantz et al. (2019) examined how the choice of formal governance structure (flat vs. hierarchical) for newly formed producer cooperative groups within Northern Ghana can affect the level of intra-group conflict. The findings of their study suggest that the efficacy of formal governance structures is highly supressed in the presence of informal governance in such contexts. Similarly, a study by Kistruck et al. (2016) involving rural communities in Sri Lanka examined how the use of alternative goals structures (competitive vs. cooperative) can affect levels of group motivation. The results indicate that while competitive goals structures can be more motivating overall in such contexts, this is highly contingent on the extent to which group members were previously familiar with one another. Because of the high levels of information asymmetry that accompany the phenomenon of 'island networks', situations in which group members were relative strangers to one another were much more motivated by cooperative goal structures as a superior means of acquiring new knowledge.

There are myriad additional research opportunities for contributing to theories of group behavior based on contextual differences stemming from the micro (individual) level. For instance, group conflict, at least in part, has been shown to be significantly affected by the 
cognitive framing of group goals (Weber, Mayer, \& Macher, 2011). Drawing upon regulatory focus theory (Higgins, 1997), prior scholars have examined whether framing group goals in a prevention or promotion manner can significantly alter resulting levels of group conflict with varying results (Haws, Dholakia, \& Bearden, 2010). However, prior work has focused almost exclusively on presenting alternative frames using formal contracting as a means of influencing group behavior. How does the effectiveness of prevention versus promotion framing differ with the use of informal contracting as is typically the case in market orchestration projects? And how does the rigidity or flexibility of predisposed information processing heuristics amongst group members moderate the nature of this relationship?

Also at the micro level, a great deal of recent work has looked at how pro-social behavior can be an important predictor of organizational and group performance (Weinstein \& Ryan, 2010). However, a great deal of this work has assumed pro-social behavior is largely an intrinsic source of motivation (Grant \& Berry, 2011). However, in contexts of extreme poverty, community members are often forced to help one another out of necessity and as a means of survival (Viswanathan, 2013). How do the outcomes of pro-social behavior differ when they are extrinsically motivated? And how resilient are such behaviors in contexts of high uncertainty as is common in market orchestration initiatives?

At the meso level, as alluded to above, group members associated with a market orchestration initiative are often members of other formal and informal groups within their tightly-knit communities. Work within social identity theory has focused extensively on how individual-level identification with certain social categories can affect a variety of organizational and group-level outcomes such as support, commitment, and task performance (Ashforth \& Mael, 1989). However, such research also notes the dangers (i.e. inter-group conflict, 
stereotyping, etc.) that can arise with the social categorization process (Li \& Hambrick, 2005). The latter is a particularly important concern to market orchestration initiatives given the multiembeddedness group members experience. One of the distinct features of market orchestration is that that producer or sales groups that are formed are often the first 'market-based' group within the community. In other words, existing groups within such communities are typically social, political, or religious in nature (Slade Shantz et al., 2018). What sorts of positive or negative 'imprinting' effects do previous social identities have on newly created market identities? And how does the degree of overlap between members of multiple groups, and their congruent or conflicting identity characteristics, influence levels of collective psychological ownership, conflict, and attrition?

In a similar vein, what implications are there for resource dependency theory (Drees \& Heugens, 2013) to explain behavior? One of the underlying assumptions of resource dependency theory in predicting behavioral outcomes is that "organizations attempt to reduce others' power over them, often attempting to increase their own power over others" (Hillman, Withers, \& Collins, 2009: 1404). However, this assumption does not typically hold in the context of market orchestration. As mentioned previously, there is typically a third-party intermediary (i.e. NGO, Association) that is actively involved in recruiting group members and formalizing group rules and responsibilities within market orchestration initiatives. As a result, in the early stages of the initiative, the third-party intermediary is often the most powerful actor. However, one of the major goals within market orchestration is to purposefully 'empower' group members as the initiative matures. How does this purposeful 'disempowerment' on the part of the most powerful external actor affect traditionally expected group outcomes? And what are the key antecedents 
and mediators necessary for an external actor to successfully undertake a transfer of power to another group actor in such contexts?

At the macro level, the governance of newly formed groups can be fairly challenging within market orchestration. More specifically, formal public institutions governing group behavior (i.e. rules and punishments) are largely absent within such contexts, which naturally gives rise to concerns of free-riding (Albanese \& Van Fleet, 1985). Ostrom's (1990) theory of collective action has triggered a body of work dedicated to understanding the key institutional design principles (i.e. boundary rules, payoff rules, etc.) required for effective collective governance (Araral, 2014). Market orchestration provides a type of hybrid phenomenon for bridging traditional work on the influence of formal market institutions (North, 1990) with work on collective action. More specifically, groups formed as part of a market orchestration initiative are neither governed primarily by public institutions nor are privately self-governed, bur rather are frequently subject to a mixture or public, private, and local third-party governance. In part, this role is fulfilled by the NGO or association as intermediary, but also present are chieftains, tribal councils, and other local actors that add another layer of complexity. Such polycentric governance (Ostrom, 2010) has received relatively scant attention at the group level of analysis. In the presence of multiple, overlapping governance institutions of varying strength, what key independent variables predict group outcomes? And under what conditions do different institutions complement, contradict, or substitute for one another?

\section{Training in New Practices}

The third component of market orchestration typically involves the training of group members in new practices. Such practices may include new agricultural processes, new administrative procedures, or new promotional efforts (Larsen \& Lilleør, 2014; London, 
Anupindi, \& Sheth, 2010). While training activities at any given time may be focused on a single group or community, often market orchestration initiatives are large in scope targeting an entire district or region of a country in aggregate (Kistruck, Beamish, et al., 2013). The undertaking of training activities shares many similarities with prominent management literatures such as human resources (Noe, Hollenbeck, Gerhart, \& Wright, 2015), knowledge transfer (Szulanski \& Jensen, 2006), and the diffusion of innovation (Rogers, 1983). Ultimately, the objective of such training is to strengthen levels of human capital (Wright, Coff, \& Moliterno, 2014).

A prominent feature of the market orchestration process as it relates to training is the extreme level of entrenchment that actors have within existing practices (McKague, Zietsma, \& Oliver, 2015). While current management literature certainly does not perceive the minds of recipients as tabula rasa, participants within market orchestration initiatives are much more highly embedded within existing practices than traditionally assumed. Part of this stems from the multiple levels of embeddedness that exist; (1) cognitively through excessive reliance on heuristics; (2) at the network level through dense social ties, and (3) culturally through adherence to informal norms and traditions (Mair et al., 2012; Sutter et al., 2017). The culmination of such forces creates significant challenges for initiating and routinizing new market practices.

Several recent studies have demonstrated how studying market orchestration can provide important insights to existing management theory. For instance Sutter et al. (2014) used a social network lens to study a Nicaraguan NGO's orchestration initiative with rural dairy farmers. The NGO wanted to train these farmers in best practices so they could produce higher quality milk for urban markets. Thus, the NGO needed to answer the practical question: "How do we teach new practices to beneficiaries?" In parallel, the authors asked the question: "How does the source of learning impact performance?" Theoretically, the paper helped to untangle how seeking 
information from peers versus experts can lead to presumptive versus principled adaptations (respectively) when modifications to existing templates are necessary as a result of resource constraints. Similarly, a study by Mair et al. (2016) involved a market orchestration initiative aimed bringing water and sanitation to rural villages in India, as well as transforming broader patterns of inequality. Their research suggests that a three-part 'scaffolding' process involving mobilizing, stabilizing, and concealing is necessary to initiate large scale change in the face of such firmly entrenched social norms.

From a micro perspective, one of the biggest practical barriers within the training component of market orchestration initiatives that simulatneously presents on opportunity for new knowledge creation is the need to overcome an inherent sense of fatalism within benficiaries. That is not to say that beneficiaries do not desire change, but that they feel an overarching lack of control over economic and social outcomes that diminishes the motivation to try new practices (Branco, 2007). As self-determination theory has highlighted, individuals can vary a great deal in the extent to which they are proactive versus passive in their attitudes towards change, and competency, autonomy, and relatedness can serve as key predictors of such attitudes (Gagne \& Deci, 2005). However, as referenced above, individual attitudes within such settings are heavily influenced by those of peers and broader societal values. How do such multilevel interactions influence the types of predictors that influence attitude change within highly fatalistic environments?

Similarly, at a micro level, training within market orchestration often infuses an economic orientation into activities that were historically seen as non-economic. For instance, many beneficiaries may view horticulture or cattle-farming as a traditional hobby rather than as a source of income (Sutter et al., 2017). However, many market orchestration initiatives involve 
the commercialization of such activities given prior experience and expertise. Work within motivation crowding theory (Frey \& Jegen, 2001) has demonstrated that the infusion of extrinsic rewards into activities that were previously intrinsically rewarding can have counter-productive effects (Pepper \& Gore, 2014). However, do such predictions hold across varying levels of financial need on the part of actors? And again, what role do social and cultural norms have in mitigating or exacerbating expectations for such 'crowding out'?

At the meso level, the novelty of the practices being trained often presents a significant practical challenge. As we know from social learning theory, much behavioral change is a result of observation of others (Bandura, 1977). Thus, rather than a simple psychological matter of operant conditioning, changing of practices often involves an environmental component in which 'learning by example' is both powerful and often necessary (Manz \& Sims, 1980). However, market orchestration initiatives often face a type of 'chicken and egg' problem in that individuals are only likely to change their practices once they see others doing so...but in the beginning nobody is willing to change (Chliova \& Ringov, 2017). Initiatives such as erecting model farms - working examples of new practices in action - have been shown to be somewhat effective, but are not always feasible given the particular context and nature of the activity being trained (Sutter et al., 2017). Thus, what types of theoretically-based interventions may be able to overcome this 'paradox of learned behavior'? Furtermore, how does the specific source of the new practice (external actor vs. internal actor) affect the likelihood of adoption? And what type of 'threshold' is required to initiate larger-scale adoption of new practices in different institutional settings?

At the macro level, the process of training new practices in a highly routinized environment represents an opportunity to study the microfoundations of institutional change 
(Cardinale, 2018). As mentioned previously, many market orchestration initiatives offer trainings at the group level, but target a large geographical area with a goal towards larger-scale change. Institutions, by their very definition, are resilient to change, and potentially even more so within contexts of extreme poverty (Mair et al., 2012). Thus, changes in individual perceptions of what practices are deemed legitimate for a new market activity can be an especially daunting task. What tactics are most effective at initiating changes in what is and what is not a legitimate practice in such environments? And what potential unintended consequences might arise (i.e. destruction of cultural institutions) from such efforts?

Also at the macro level, the process of market orchestration offers the potential to bring systems theory thinking (Ashmos \& Huber, 1987) more into the management domain. Traditionally emerging from the field of biology, there have been increasing attempts amongst management scholars to apply such thinking to aid in the understanding of industry and organizational change (Head \& Alford, 2015). However, market environments are typically so complex that many argue the theory suffers from a lack of tractability (Schad \& Bansal, 2018). However, market orchestration initiatives often involve a much smaller and more clearly defined set of suppliers, buyers, and local stakeholders in a relatively isolated setting (Kistruck, Beamish,

et al., 2013). This comparatively narrow scope of actors and activities provides an important 'boundary' to the system, and thus allows for a more manageable set of variables to understand the microfoundations of system-level changes in market practices and behaviors.

\section{Facilitating New Transactional Linkages}

The fourth component in the market orchestration process involves the development of new linkages for the purpose of creating or improving market exchange. Such linkages can be downstream (i.e. connecting beneficiaries to new customers) or upstream (i.e. connecting 
beneficiaries to new sources of inputs and supply) in nature. The study of such linkages overlaps significantly with existing literatures of transactional governance and principal-agent arrangements, with accompanying theories of transaction cost economics (Williamson, 1985), agency theory (Eisenhardt, 1989), and incomplete contracting theory (Grossman \& Hart, 1986). However, the context of market orchestration possesses several characteristics that challenge the underlying assumptions of such theories. For example, such theories are grounded on the assumptions of maximizing self-interest and the pursuit of economic efficiency (Eisenhardt, 1989). However, actors transacting within market orchestration initiatives are typically at least in part 'other-interested', and the goals they seek are often a mixture of both economic and noneconomic. Viswanathan and colleagues (Viswanathan, 2013; Viswanathan, Gajendiran, \& Venkatesan, 2008) make this clear in their robust studies of subsistence marketplaces when they show just how socially complex the concept of a 'market' can be, with familial and community considerations being interwoven with economic considerations.

Current economic theories are often dyadic in their orientation - seeing decisions regarding the structuring of transactions between two direct actors (Ellis, 2003). However, market orchestration typically involves one or more intermediaries as a third party within the transactions. Given the sheer complexity of market orchestration interventions including the number of partners involved, and their different functional backgrounds (Lindeman, 2012; Mason \& Chakrabarti, 2017), there is ample opportunity to enrich theory by considering using these interventions to push the boundaries of theories focusing on dyadic transactions. Existing theories also largely assume that transactions are structured within an environment consisting of well-developed formal market institutions to assist in the monitoring and enforcement of contractual breaches (North, 1990). Comparatively, contexts of market orchestration are often 
described as having formal institutional voids (Mair et al., 2012). While emergent streams of research such as relational contracting (Bosse \& Phillips, 2016), base-of-the-pyramid markets (Hart \& London, 2004), and the informal economy (Webb, Tihanyi, Ireland, \& Sirmon, 2009) have begun to explore how relaxing such assumptions may modify the predictions of current transactional theories, there is a great deal more opportunity to make meaningful contributions from the study of market orchestration.

For example, a study by Kistruck et al. (2013) examined 29 different market orchestration projects in Africa, Latin America, and South Asia. More specifically, the study explored how an 'other-interested' motivation on the part of a third-party intermediary would alter the decision to internalize versus externalize certain transactional activities. They inductively theorize that 'socialficing' on the part of an intermediary can significantly alter such decisions in a complex rather than straightforward manner. Similarly, another study by involved the creation of new upstream linkages between an NGO and rural consumers with health problems in Guatemala (Kistruck, Sutter, Lount Jr., \& Smith, 2013). As opposed to transacting directly with consumers, the NGO was required to use local sales groups to distribute their projects but was experiencing significant agency costs as a result. As an alternative to existing agency theory prescriptions regarding outcome-based versus behavior-based contracts which were both ineffective in this environment, the authors explored how identity-based mechanisms can act as effective governance substitutes. By integrating agency theory with identity theory, the authors helped to reconcile previous conflicting findings within the management literature.

From a micro perspective, one of the most salient features of beneficiaries within such contexts as it relates to transacting is an extreme short-term orientation (Banerjee \& Duflo, 2011). More specifically, research has shown that highly impoverished individuals are likely to 
focus on very immediate needs (Mullainathan \& Shafir, 2013). Conversely, orchestrating new market linkages often requires engaging in repeated longer-term relationships with buyers and sellers, and the success of such initiatives hinges on a commitment to such relationships. However, a short-term orientation, coupled with exchange conditions in which spot-market transacting predominate, make undertaking such an adjustment extremely difficult. How do preexisting biases factor into existing contracting theories that are largely ahistorical and typically minimize such individual-level constraints? And what sorts of cognitive interventions, and associated changes in mediating mental states, can be successful in overcoming such biases?

At a meso level, the creation of new transactional ties during the process of market orchestration often means the dismantling or redefining of existing ties. Indeed, much of the market activity that currently exists in such contexts is dominated by exploitative middlemen (Vachani \& Smith, 2008), and thus finding new exchange partners is key to ensuring beneficiaries capture a large percentage of the value they create. However, economic ties within such 'island networks' (Slade Shantz et al., 2018) are often tightly intertwined with social and even familial ties that add a significant layer of complexity when attempting to make such changes. Social network theory (Granovetter, 1983) is particularly helpful in explaining and predicting how different types and configurations of ties affects individual, group, and organizational behavior, including networks that are socio-centric and have a high degree of tie multiplicity (Marsden, 2002). However, further insight is needed into how the introduction of heterogeneous ties (through the forming of linkages with new outsiders) affects networks traditionally comprised of high levels of homophily. To what extent do weak ties (versus strong ties) allow for decreased multiplicity without negatively impacting the entire network? And what are the different antecedents and mechanisms for redefining existing non-market ties in such 
highly socio centric networks (i.e. from seeing a wife as not simply providing social support, but also as providing economic support to the family)?

Finally, at a macro level, one of the biggest difficulties in market orchestration initiatives is finding ways to decrease transaction costs to the point at which trade equitable and profitable trade is a possibility (Parmigiani \& Rivera-Santos, 2015). In the absence of strong formal market institutions, the costs associated with facilitating new trade linkages are borne privately by the actors involved. Transaction cost economics (Williamson, 1985) provides an extremely useful framework for studying the reduction of ex ante and ex post costs associated with search, negotiation, monitoring, and enforcement. However, the types of new linkages formed within market orchestration initiatives often span the formal with the informal economy (De Soto, 2000; Kistruck, Beamish, et al., 2013). How does the process of building and managing transactions across two very different institutional environments impact current predictions? For example, in such contexts, are traditionally-research structures (i.e. joint-ventures, alliances, etc.) still applicable, or are there other types of hybrid governance that emerge? And what are the most salient factors predicting structural choice - do they remain asset specificity, frequency, and uncertainty or are there other important factors at play? Infusing notions of institutional multiplicity and polycentricity (Ostrom, 2010) into mainstream transactional theories may help strengthen their explanatory and predictive capabilities.

\section{DISCUSSION}

A growing number of management scholars are calling for increased relevance in the discipline (McGahan, 2007), as well as for a focus on pressing societal Grand Challenges (Banks et al., 2016; George, Howard-Grenville, et al., 2016). The context of market orchestration naturally enables both theoretical relevance and contributions to societal Grand Challenges. 
Underpinning this is the fact that development interventions have scores of challenges, leaving no shortage of avenues for combining theory and practice (Banerjee \& Duflo, 2011; Glennerster \& Takavarasha, 2013; Karlan \& Appel, 2016). By deconstructing the phenomenon of market orchestration and highlighting how its contextual distinct aspects present gaps within current management literature, we attempt to build a stronger link between theory and practice.

\section{A model for theory development}

Our primary goal in authoring this paper is helping people publish their passion. The sharp increase in authors exploring market orchestration and poverty is a testament to growing interest in this undertaking. However, we believe the pursuit of poverty-related research has been stifled because of difficulties linking passion - poverty alleviation - to the core of academic publishing - theory development. With the above examples drawn out, we introduce in Figure 1 a conceptual process for building theory through studying market orchestration. Analysis starts with understanding which of the four market orchestration components are relevant.

Insert Figure 1 about here

In parallel, understanding contextual differences is key, as these represent what is fundamentally different about the context. Table 1 provides example differences and expands on why these may be theoretically relevant. This list is not exhaustive, but it provides a robust starting point for theorizing. We have grouped it into micro, meso, and macro factors to highlight that authors may consider, respectively, what is different about individual cognition, what is different about social and organizational ties, or what is generally different about the environment? From here, specifics about the market orchestration initiative and the salient contextual differences should guide which theories may be of interest as alluded to in the examples in 
Table 2 and Table 3. For instance, perhaps group formation is core to the initiative. While a broad assortment of organizational behaviour theories can speak to organizing groups, not all may make sense. Theories of trust may in general be important to group organization, but perhaps levels of pre-existing trust seem not to be any different than normally assumed in the literature. It may thus be difficult to pivot theorizing around trust. Conversely, perhaps beneficiaries seem especially risk-averse. This suggests a need to pivot to literature focusing on motivation, and perhaps the process of building group identities (identities that practically should be risk-tolerant).

Exploring theory development based on the interaction of specific theories with specific contextual differences is an ongoing iterative process. As a researcher gains a better understanding of a market orchestration initiative, new contextual differences become clearer, opening new theories for consideration. As part of this iteration, a core focus is understanding how the salient contextual differences challenge assumptions of the relevant theories. If the contextual elements do not challenge any assumptions, there is no unique avenue for theory development. Theory may still be developed, such as through the "normal" incremental advancement of a theory, but this is not our focus here as this undersells the theoretical generativity of the context. Instead, the process of challenging assumptions allows uniquely insightful avenues for informing theory. In turn, these lead to the research questions around which a paper is based, and to the ultimate contribution.

Overall, building theory from the practice of market orchestration is a time-consuming undertaking. Finding a viable route of inquiry is never straightforward. However, discussions with co-investigators and with uninvolved colleagues often illuminate what is truly unique and promising. It has often taken us many months to isolate a generative line of inquiry, especially 
when having to consider methodological challenges (Kriauciunas, Parmigiani, \& Rivera-Santos, 2011).

\section{A model for practical development}

To ensure relevance to the world's Grand Challenges, our framework for theory development includes a strong practical focus. First, and as seen at the top of Figure 1, the process should start with a consideration of the practical challenges faced by the organization implementing a market orchestration initiative. These challenges are embedded in turn in a specific component of the initiative - e.g. there are high levels of group conflict, or beneficiaries are not learning the needed farming techniques. Critically, most challenges come about because of the contextually unique nature of market orchestration - e.g. there are high levels of group conflict because of overlapping social networks, or beneficiaries are not learning the needed farming techniques because of fatalism and/or risk-aversion. In fact, if a challenge is not coming about because of a contextually distinct element, this implies that existing theory likely already offers a solution so A) a researcher should tell this to the organization, and B) there is nothing theoretically interesting to be developed from that challenge. Moreover, some contextually unique factors are part of potential solutions to the practical challenges; e.g. communal orientations can be leveraged to build a community-focused identity that mutes separate ethnic ones, or crop techniques can be taught in a modified manner through traditional institutions in order to increase legitimacy of the knowledge.

Second, and at the bottom of Figure 1, the iteration process should grow to include consideration of whether proposed theoretical outcomes are likely to give practical insights. Core to this is how research questions may pair with the practical questions an organization is asking. For theorizing to be practically relevant, the examined constructs must be controllable by the 
development organization. For instance, learning that community population impacts group performance is of only marginal use. Much more practically relevant (and theoretically interesting) would be exploring a set of independent variables embedded in different strategies for improving group performance. In this instance, it may become especially relevant if we learn that community population is an important moderator of the success of these strategies.

\section{Ensuring an ethical approach for both practitioners and researchers}

We encourage practitioners to be highly cognizant of the ongoing ethical considerations associated with market orchestration as an interventionist approach. In centering our work on market orchestration, a core consideration is the definition of a market. We focus on markets as sites for the exchange of money, goods, and services, which aligns with the focus of market orchestration activities, and is the view held in much of the management literature. Yet, this view should not diminish the importance of other market functions, such as social and redistributive functions. As we point out in several of our examples, by focusing on exactly these types of additional functions, implicit theoretical assumptions can be challenged (e.g. a narrow view of markets), and the theoretical corpus expanded. Critically, integrating expanded views of market function and activity will help researchers avoid imposing a neocolonial definition of markets that may unintendedly strip away context specific market functions.

Another core ethical consideration of market orchestration comes from its reliance on changing something in local communities - namely the nature of specific markets. Underly such actions are omnipresent ethical qualms about the duty to intervene and address poverty, versus the right of local communities to autonomy and self-determination. Moreover, and considering that many intervening organizations come from Western, Educated, Industrialized, Rich, and Democratic contexts (i.e. WEIRD, Henrich et al., 2010) whose ethical norms differ substantially 
from those in the Global South (Shweder, Much, Mahapatra, \& Park, 1997), there are very real concerns about the imperial imposition WEIRD market norms. Yet at the same time, and given that markets in many contexts are fundamentally exclusionary (Mair et al., 2012), there are also real concerns with taking a moral relativism approach and accepting local norms as the ultimate arbiter of right or wrong (Donaldson, 1996).

One way of balancing these ethical concerns is to consider the hierarchy of different ethical norms (Donaldson \& Dunfee, 1994). For instance, Donaldson and Dunfee (1999: 47) point to the overarching hypernorm of "necessary social efficiency" which dictates that a highlevel moral prerogative is to "enable people to achieve basic or 'necessary' social goods...such as health, education, housing, food, clothing, and social justice." If this is taken as a foundational norm, then the fundamental premise of market orchestration - poverty alleviation - can be argued is justified, even if lower-order ethical norms are put into conflict. Put another way, when people are living in substantive material deprivation, there are not only ethical consequences of doing something, but also of doing nothing. Of course, this cannot be taken as an overarching justification for any type of market orchestration, as some interventions are demonstrably harmful (Levien, 2015). However, considering the hierarchy of different norms helps to provide a framework for dealing with potential ethical conflicts.

Practitioners also need to be acutely aware of the unintended consequences that can accompany market orchestration initiatives (Lambe et al., 2020). For instance, orchestrating markets to foster cash cropping may increase incomes of individual farmers, but it also makes producers vulnerable to global fluctuations in prices and the risks inherent therein (Mohan, 2016). At a social network level, the orchestration of markets can upend existing social relationships: "monetization of individual social networks is likely to cannibalize trust and 
undermine existing norms, and in the process reduce the solidarity necessary for collective action...especially in conditions of rapid socio-economic change" (Levien, 2015: 88). This outcome is inherently problematic, as it replaces previously beneficial relationships with market forces that do not provide security in times of need, and this loss is largely irreversible. Additionally, development organizations may unwittingly push interventions that are ill-suited for the context, something the authors have seen repeatedly, such as with honey production in illsuited arid regions. This wastes the time of those who have sorely little of it. Overall, engaging with local communities, carefully mapping interventions, employing pilot studies, and continuously monitoring are key not only to developing successful interventions, but also to gaining insights into unintended consequences (Lambe et al., 2020)

Finally, we also want to stress the importance of "do no harm" from a researcher perspective. Development interventions work with the most vulnerable populations in the world, and it is wholly inappropriate to view these individuals as but a testbed for theory development. Interventions can have very dire real world consequences from the individual to the national levels (Clementi, Molini, \& Schettino, 2018). Though the ethics of international development research are complex and take up many volumes (Gaspar, 2014; Okereke, 2008; Schwenke, 2009), we lay out three core rules to consider. First, a researcher cannot make beneficiaries worse off than if they did not take part in an intervention. In practice, this is not straightforward, as it is possible an intervention will help $9 / 10$ people but make a tenth worse off. Should it be undertaken? We cannot answer that, but everything should be done to minimize the potential harm to the tenth. Second, interventions must do some good. Even if an intervention were hypothetically neutral harm-wise, the opportunity costs for participants and the organization make this ethically dubious. Instead of spending time on a "neutral" intervention, beneficiaries 
could be farming, and organization staff could be doing other productive activities. Third, every effort must be made to understand the possible unintended consequences, as these are both everpresent and ever-harmful in development interventions (Levien, 2015; Lupton, 2011; Moyo, 2009). Key to avoiding unintended consequence are pilot projects, frequent discussions with project staff, and researcher immersion in the context all facilitate this. 


\section{REFERENCES}

Academy of Management. 2010. AOM 2010 Theme. Dare to Care: Passion and Compassion in Management Practice and Research. http://aom.org/Meetings/annualmeeting/pastmeetings/theme2010.aspx.

Academy of Management. 2016. AOM 2016 Theme: Making Organizations Meaningful. http://aom.org/annualmeeting/2016/theme/.

Academy of Management. 2018. AOM 2018 Theme: Improving Lives. https://aom.org/Meetings/annualmeeting/2018/AOM-2018-Theme-Improving-Lives.aspx.

Albanese, R., \& Van Fleet, D. D. 1985. The free riding tendency in organizations. Scandinavian Journal of Management Studies, 2(2): 121-136.

Alkire, S., Roche, J. M., \& Vaz, A. 2017. Changes Over Time in Multidimensional Poverty: Methodology and Results for 34 Countries. World Development, 94: 232-249.

Alvarez, S. A., \& Barney, J. B. 2014. Entrepreneurial Opportunities and Poverty Alleviation. Entrepreneurship Theory and Practice, 38(1): 159-184.

Amoako, I. O., \& Lyon, F. 2014. 'We don't deal with courts': Cooperation and alternative institutions shaping exporting relationships of small and medium-sized enterprises in Ghana. International Small Business Journal, 32(2): 117-139.

Andrews, M., Pritchett, L., \& Woolcock, M. 2017. Building State Capability. Building State Capability.

Ansari, S., Munir, K., \& Gregg, T. 2012. Impact at the "Bottom of the Pyramid": The role of social capital in capability development and community empowerment. Journal of Management Studies, 49(4): 813-842.

Araral, E. 2014. Policy and regulatory design for developing countries: a mechanism design and transaction cost approach. Policy Sciences, 47(3): 289-303.

Armanios, D. E., Eesley, C. E., Li, J., \& Eisenhardt, K. M. 2017. How entrepreneurs leverage institutional intermediaries in emerging economies to acquire public resources. Strategic Management Journal, 38(7): 1373-1390.

Asadullah, M. N., \& Ara, J. 2016. Evaluating the long-run impact of an innovative anti-poverty programme: evidence using household panel data. Applied Economics, 48(2): 107-120.

Asadullah, M. N., \& Savoia, A. 2018. Poverty reduction during 1990-2013: Did millennium development goals adoption and state capacity matter? World Development, 105: 70-82.

Asadullah, M. N., Savoia, A., \& Mahmud, W. 2014. Paths to Development: Is there a Bangladesh Surprise? World Development, 62: 138-154.

Ashforth, B. E., \& Mael, F. 1989. Social Identity Theory and the Organization. Academy of Management Review, 14(1): 20-39.

Ashmos, D. P., \& Huber, G. P. 1987. The Systems Paradigm in Organization Theory: Correcting the Record and Suggesting the Future. The Academy of Management Review, 12(4): 607.

Autio, E., \& Fu, K. 2015. Economic and political institutions and entry into formal and informal entrepreneurship. Asia Pacific Journal of Management, 32(1): 67-94.

Baker, R. W. 2005. Capitalism's Achilles Heel: Dirty Money and How to Renew the FreeMarket System.

Baker, T., \& Welter, F. 2018. Contextual Entrepreneurship: An Interdisciplinary Perspective. Foundations and Trends in Entrepreneurship, 14(4): 357-426.

Bandura, A. 1977. Social Learning Theory. Englewood Cliffs, NJ: Prentice Hall.

Banerjee, A., Karlan, D., \& Zinman, J. 2015. Six Randomized Evaluations of Microcredit: 
Introduction and Further Steps. American Economic Journal: Applied Economics, 7(1): 121.

Banerjee, A. V., \& Duflo, E. 2011. Poor Economics: A radical rethinking of the way to fight global poverty (PublicAffairs). New York, NY: PublicAffairs.

Banks, G. C., Pollack, J. M., Bochantin, J. E., Kirkman, B. L., Whelpley, C. E., et al. 2016. Management's science-practice gap: A grand challenge for all stakeholders. Academy of Management Journal, 59(6): 2205-2231.

Barnard, H., Cuervo-Cazurra, A., \& Manning, S. 2017. Africa Business Research as a Laboratory for Theory-Building: Extreme Conditions, New Phenomena, and Alternative Paradigms of Social Relationships. Management and Organization Review, 13(3): 467495.

Baron, R. A. 2006. Opportunity Recognition as Pattern Recognition: How Entrepreneurs "Connect the Dots" to Identify New Business Opportunities. Academy of Management Perspectives, 20(1): 104-119.

Basu, R., Banerjee, P., \& Sweeny, E. 2013. Frugal Innovation: Core Competencies to Address Global Sustainability. Journal of Management for Global Sustainability, 1(2): 63-82.

Bendersky, C., \& Hays, N. A. 2012. Status Conflict in Groups. Organization Science, 23(2): 323-340.

Bosse, D. A., \& Phillips, R. A. 2016. Agency Theory and Bounded Self-Interest. Academy of Management Review, 41(2): 276-297.

Boyacigiller, N. A., \& Adler, N. J. 1991. The Parochial Dinosaur: Organizational Science in a Global Context. Academy of Management Review, 16(2): 262-290.

Bradley, S. W., McMullen, J. S., Artz, K., \& Simiyu, E. M. 2012. Capital Is Not Enough: Innovation in Developing Economies. Journal of Management Studies, 49(4): 684-717.

Branco, M. C. 2007. Family, religion and economic performance: A critique of cultural determinism. Review of Social Economy, 65(4): 407-424.

Brass, J. N., Longhofer, W., Robinson, R. S., \& Schnable, A. 2018. NGOs and international development: A review of thirty-five years of scholarship. World Development, 112: 136149.

Brief, A. P., \& Weiss, H. M. 2002. Organizational Behavior: Affect in the Workplace. Annual Review of Psychology, 53(1): 279-307.

Bruton, G. D., Ketchen, D. J., \& Ireland, R. D. 2013. Entrepreneurship as a solution to poverty. Journal of Business Venturing, 28(6): 683-689.

Bullough, A., Renko, M., \& Myatt, T. 2014. Danger zone entrepreneurs: The importance of resilience and self-efficacy for entrepreneurial intentions. Entrepreneurship Theory and Practice, 38(3): 473-499.

Cardinale, I. 2018. Beyond Constraining and Enabling: Toward New Microfoundations for Institutional Theory. Academy of Management Review, 43(1): 132-155.

Chen, C. C., Greene, P. G., \& Crick, A. 1998. Does entrepreneurial self-efficacy distinguish entrepreneurs from managers? Journal of Business Venturing, 13(4): 295-316.

Chliova, M., \& Ringov, D. 2017. Scaling Impact: Template Development and Replication at the Base of the Pyramid. Academy of Management Perspectives, 31(1): 44-62.

Clementi, F., Molini, V., \& Schettino, F. 2018. All that Glitters is not Gold: Polarization Amid Poverty Reduction in Ghana. World Development, 102: 275-291.

Cooney, K., \& Shanks, T. R. W. 2010. New Approaches to Old Problems: Market-Based Strategies for Poverty Alleviation. Social Service Review, 84(1): 29-55. 
Dana, L. P., \& Anderson, R. B. 2007. Taos Pueblo: an indigenous community holding on to Promethean values. Journal of Enterprising Communities: People and Places in the Global Economy, 1(4): 321-336.

Davis, B., Winters, P., Carletto, G., Covarrubias, K., Quiñones, E. J., et al. 2010. A cross-country comparison of rural income generating activities. World Development, 38(1): 48-63.

Dawson, N., Martin, A., \& Sikor, T. 2016. Green Revolution in Sub-Saharan Africa: Implications of Imposed Innovation for the Wellbeing of Rural Smallholders. World Development, 78: 204-218.

De Soto, H. 2000. The mystery of capital: Why capitalism triumphs in the west and fails everywhere else. New York: Basic Books.

Dencker, J., Bacq, S. C., Gruber, M., \& Haas, M. 2019. Reconceptualizing necessity entrepreneurship: A contextualized framework of entrepreneurial processes under the condition of basic needs. Academy of Management Review, (In Press).

Donaldson, T. 1996. Values in tension: Ethics away from home. Harvard Business Review.

Donaldson, T., \& Dunfee, T. W. 1994. Toward A unified conception of business ethics: Integrative Social Contracts Theory. Academy of Management Review, 19(2): 252-284.

Donaldson, T., \& Dunfee, T. W. 1999. When ethics travel: The promise and peril of global business ethics. California Management Review, (4): 45-63.

Drees, J. M., \& Heugens, P. P. M. A. R. 2013. Synthesizing and Extending Resource Dependence Theory. Journal of Management, 39(6): 1666-1698.

Dutt, N., Hawn, O., Vidal, E., Chatterji, A., McGahan, A., et al. 2016. How Open System Intermediaries Address Institutional Failures: The Case of Business Incubators in Emerging-Market Countries. Academy of Management Journal, 59(3): 818-840.

Easterly, W. 2006. The White man's burden: Why the West's efforts to aid the rest have done so much ill and so little good. New York: Penguin.

Eisenhardt, K. M. 1989. Agency Theory: An Assessment and Review. Academy of Management Review., 14(1): 57-74.

Ellis, P. D. 2003. Social Structure and Intermediation: Market-making Strategies in International Exchange. Journal of Management Studies, 40(November): 1683-1708.

Fedderke, J. W., Perkins, P., \& Luiz, J. M. 2006. Infrastructural investment in long-run economic growth: South Africa 1875-2001. World Development, 34(6): 1037-1059.

Ferrière, N., \& Suwa-Eisenmann, A. 2015. Does Food Aid Disrupt Local Food Market?

Evidence from Rural Ethiopia. World Development, 76: 114-131.

Fiske, S., \& Taylor, S. 1991. Social Cognition. McGraw-Hill.

Frey, B. S., \& Jegen, R. 2001. Motivation crowding theory. Journal of Economic Surveys, 15(5): 589-611.

Gaglio, C. M., \& Katz, J. a. 2001. The Psychological Basis of Opportunity Identification: Entrepreneurial Alertness. Small Business Economics, 16(2): 95-111.

Gagne, M., \& Deci, E. L. 2005. Self-determination theory and work motivation. Journal of Organizational Behavior, 26(June 2004): 331-362.

Gaspar, D. 2014. Ethics and Development. The companion to development studies2. New York: Routledge.

George, G., Corbishley, C., Khayesi, J. N. O., Haas, M. R., \& Tihanyi, L. 2016. Bringing Africa in: Promising Directions for Management Research. Academy of Management Journal, 59(2): 377-393.

George, G., Howard-Grenville, J., Joshi, A., \& Tihanyi, L. 2016. Understanding and tackling 
societal grand challenges through management research. Academy of Management Journal, 59(6): 1880-1895.

George, G., McGahan, A. M., \& Prabhu, J. 2012. Innovation for Inclusive Growth: Towards a Theoretical Framework and a Research Agenda. Journal of Management Studies, 49(4): 661-683.

Giesbert, L., \& Schindler, K. 2012. Assets, Shocks, and Poverty Traps in Rural Mozambique. World Development, 40(8): 1594-1609.

Glennerster, R., \& Takavarasha, K. 2013. Running randomized evaluations: A practical guide. Princeton and Oxford: Princeton University Press.

Granovetter, M. 1983. The strength of weak ties: A network theory revisited. Sociological Theory, 1(1983): 201.

Grant, A. M., \& Berry, J. W. 2011. The Necessity of Others is The Mother of Invention: Intrinsic and Prosocial Motivations, Perspective Taking, and Creativity. Academy of Management Journal, 54(1): 73-96.

Gras, D., Kistruck, G., Neda, Y., \& Bruton, G. D. 2018. Comparative Approaches for Spurring Innovative Opportunities in Base-Of-The-Pyramid Markets. Academy of Management Proceedings, 2018(1): 11082.

Grossman, S. J., \& Hart, O. D. 1986. The Costs and Benefits of Ownership: A Theory of Vertical and Lateral Integration. Journal of Political Economy, 94(4): 691-719.

Haider, L. J., Boonstra, W. J., Peterson, G. D., \& Schlüter, M. 2018. Traps and Sustainable Development in Rural Areas: A Review. World Development, 101: 311-321.

Handelman, H., \& Brynen, R. 2019. Challenges of the Developing World. Rowman \& Littlefield Publishers.

Harman, S., \& Williams, D. 2014. International development in transition. International Affairs, 90(4): 925-941.

Hart, K. 2011. Informal income opportunities and urban employment in Ghana. Journal of Modern African Studies, 11(1): 61-89.

Hart, S. L., \& Christensen, C. M. 2002. The Great Leap: Driving Innovation from the Base of the Pyramid. MIT Sloan Management Review, 44(1): 51-56.

Hart, S. L., \& London, T. 2004. Reinventing Strategies for Emerging Markets: Beyond the Transnational Model Reinventing strategies for emerging markets: beyond the transnational model. Journal of International Business Studies, 35(5): 350-370.

Haws, K. L., Dholakia, U. M., \& Bearden, W. O. 2010. An Assessment of Chronic Regulatory Focus Measures. Journal of Marketing Research, 47(5): 967-982.

Head, B. W., \& Alford, J. 2015. Wicked Problems: Implications for Public Policy and Management. Administration and Society, 47(6): 711-739.

Henrich, J., Heine, S. J., \& Norenzayan, A. 2010. The weirdest people in the world? The Behavioral and Brain Sciences, 33(2-3): 61-83; discussion 83-135.

Higgins, E. T. 1997. Beyond pleasure and pain. American Psychologist, 52(12): 1280-1300.

Hillman, A. J., Withers, M. C., \& Collins, B. J. 2009. Resource Dependence Theory: A Review. Journal of Management, 35(6): 1404-1427.

Hoey, L. 2017. Reclaiming the Authority to Plan: How the Legacy of Structural Adjustment Affected Bolivia's Effort to Recentralize Nutrition Planning. World Development, 91: 100112.

Hulme, D., \& Shepherd, A. 2003. Conceptualizing chronic poverty. World Development, 31(3): 403-423. 
ILO. 2016. Start and improve your business program. http://www.ilo.org/declaration/lang-en/index.htm.

Karlan, D., \& Appel, J. 2016. Failing in the field: What we can learn when field research goes wrong. Princeton and Oxford: Princeton University Press.

Khayesi, J. N. O., \& George, G. 2011. When does the socio-cultural context matter? Communal orientation and entrepreneurs' resource accumulation efforts in Africa. Journal of Occupational and Organizational Psychology, 84(3): 471-492.

Kirzner, I. 1985. Discovery and the capitalist process. Chicago: University of Chicago Press.

Kistruck, G. M., Beamish, P. W., Qureshi, I., \& Sutter, C. J. 2013. Social Intermediation in Baseof-the-Pyramid Markets. Journal of Management Studies, 50(1): 31-66.

Kistruck, G. M., Lount, R. B., Smith, B. R., Bergman, B. J., \& Moss, T. W. 2016. Cooperation vs. Competition: Alternative Goal Structures for Motivating Groups in a Resource Scarce Environment. Academy of Management Journal, 59(4): 1174-1198.

Kistruck, G. M., Sutter, C. J., Lount Jr., R. B., \& Smith, B. R. 2013. Mitigating principal-agent problems in base-of-the-pyramid markets: An identity spillover perspective. Academy of Management Journal, 56(3): 659-682.

Knight, G. A., \& Cavusgil, S. T. 2004. Innovation, Organizational Capabilities, and the BornGlobal Firm. Journal of International Business Studies, 35(2): 124-141.

Kolk, A., Rivera-Santos, M., \& Rufín, C. 2014. Reviewing a Decade of Research on the "Base/Bottom of the Pyramid" (BOP) Concept. Business and Society, 53(3): 338-377.

Kreiner, G., Hollensbe, E., \& Sheep, M. 2009. Balancing borders and bridges: Negotiating the work-home interface via boundary work tactics. Academy of Management Journal, 52(4): 704-730.

Kriauciunas, A., Parmigiani, A., \& Rivera-Santos, M. 2011. Leaving our comfort zone: Integrating established practices with unique adaptations to conduct survey-based strategy research in nontraditional contexts. Strategic Management Journal, 32(9): 994-1010.

Lambe, F., Ran, Y., Jürisoo, M., Holmlid, S., Muhoza, C., et al. 2020. Embracing complexity: A transdisciplinary conceptual framework for understanding behavior change in the context of development-focused interventions. World Development, 126: 104703.

Larsen, A. F., \& Lilleør, H. B. 2014. Beyond the Field: The Impact of Farmer Field Schools on Food Security and Poverty Alleviation. World Development, 64: 843-859.

Lazzarini, S. G., Miller, G. J., \& Zenger, T. R. 2004. Order with some law: Complementarity versus substitution of formal and informal arrangements. Journal of Law, Economics, and Organization, 20(2): 261-298.

Levien, M. 2015. Social Capital as Obstacle to Development: Brokering Land, Norms, and Trust in Rural India. World Development, 74: 77-92.

Li, J., \& Hambrick, D. C. 2005. Factional Groups: A New Vantage on Demographic Faultlines, Conflict, and Disintegration in Work Teams. Academy of Management Journal, 48(5): 794-813.

Lindeman, S. 2014. "Until We Live Like They Live in Europe": A Multilevel Framework for Community Empowerment in Subsistence Markets. Journal of Macromarketing, 34(2): 171-185

Lindeman, S. 2012. Market formation in subsistence settings: A study of informal waste trade practices in Tanzania and Brazil. Consumption Markets \& Culture. 15(2): 235-257.

London, T., Anupindi, R., \& Sheth, S. 2010. Creating mutual value: Lessons learned from ventures serving base of the pyramid producers. Journal of Business Research, 63(6): 582- 
594.

London, T., Esper, H., Grogan-Kaylor, A., \& Kistruck, G. M. 2014. Connecting poverty to purchase in informal markets. Strategic Entrepreneurship Journal, 8(1): 37-55.

Lumpkin, G. T., \& Dess, G. G. 1996. Clarifying the Entrepreneurial Orientation Construct and Linking It to Performance. The Academy of Management Review, 21(1): 135.

Lupton, R. 2011. Toxic Charity. New York: HarperOne.

Mair, J., \& Martí, I. 2006. Social entrepreneurship research: A source of explanation, prediction, and delight. Journal of World Business, 41(1): 36-44.

Mair, J., Martí, I., \& Ventresca, M. J. 2012. Building inclusive markets in rural Bangladesh: How intermediaries work institutional voids. Academy of Management Journal, 55(4): 819-850.

Mair, J., Wolf, M., \& Seelos, C. 2016. Scaffolding: A Process of Transforming Patterns of Inequality in Small-Scale Societies. Academy of Management Journal, 59(6): 2021-2044.

Manz, C. C., \& Sims, H. P. 1980. Self-Management as a Substitute for Leadership: A Social Learning Theory Perspective. Academy of Management Review, 5(3): 361-367.

Marsden, P. V. 2002. Egocentric and sociocentric measures of network centrality. Social Networks, 24(4): 407-422.

Martin, B. C., McNally, J. J., \& Kay, M. J. 2013. Examining the formation of human capital in entrepreneurship: A meta-analysis of entrepreneurship education outcomes. Journal of Business Venturing, 28(2): 211-224.

Mason, K., Chakrabati R. 2017. The role of proximity in Business model design: Making Business models work for those at the bottom of the pyramid. Industrial Marketing Management, 61: 67-80.

McGahan, A. M. 2007. Academic research that matters to managers: On zebras, dogs, lemmings, hammers, and turnips. Academy of Management Journal, 50(4): 748-753.

McKague, K., Zietsma, C., \& Oliver, C. 2015. Building the Social Structure of a Market. Organization Studies, 36(8): 1063-1093.

Meredith, M. 2011. The fate of Africa: A history of the continent since independence. PublicAffairs.

Mohan, S. 2016. Institutional Change in Value Chains: Evidence from Tea in Nepal. World Development, 78: 52-65.

Morgan, E. A., Power, G. D., \& Weigel, V. B. 1993. Thinking strategically about development: A typology of action programs for global change. World Development, 21(12): 1913-1930.

Moyo, D. 2009. Dead Aid: Why aid is not working and how there is a batter way for Africa. Canada: Douglas \& McIntyre.

Mullainathan, S., \& Shafir, A. 2013. Scarcity: Why having too little means so much. New York: Times Books, Henry Holt and Company.

Narayan, D., \& Petesch, P. 2002. Voices of the poor: From many lands. Washington DC: The World Bank.

Noe, R. A., Hollenbeck, J. R., Gerhart, B., \& Wright, P. M. 2015. Fundamentals of Human Resource Management. New York: McGraw-Hill.

North, D. C. 1990. Institutions, institutional change and economic performance. Cambridge, UK: Cambridge University Press.

Oberdabernig, D. A. 2013. Revisiting the Effects of IMF Programs on Poverty and Inequality. World Development, 46: 113-142.

Okereke, C. 2008. Global justice and neoliberal environmental governance: Ethics, 
sustainable development and international co-operation. New York: Routledge.

Onyas W.I., McEachern, M. G., \& Ryan, A., 2018. Co-constructing sustainability: Agencing sustainable coffee farmers in Uganda. Journal of Rural Studies, 61: 12-21.

Onyas, W.W. \& Ryan A., 2015, Agencing markets: Actualizing ongoing markets innovation. Industrial Marketing Management, 44: 13-21.

Ostrom, E. 1990. Governing the Commons: The Evolution of Institutions for Collective Action. Cambridge, UK: Cambridge University Press.

Ostrom, E. 2010. A Long Polycentric Journey. Annual Review of Political Science, 13(1): 1-23.

Ouattara, B. 2007. Foreign aid, public savings displacement and aid dependency in Côte d'Ivoire: An aid disaggregation approach. Oxford Development Studies, 35(1): 33-46.

Palich, L. E., \& Bagby, D. 1995. Using cognitive theory to explain risk taking: Challenging Conventional Wisdom. Journal of Business Venturing, 10(6): 425-438.

Parmigiani, A., \& Rivera-Santos, M. 2015. Sourcing for the base of the pyramid: Constructing supply chains to address voids in subsistence markets. Journal of Operations Management, 33-34: 60-70.

Pepper, A., \& Gore, J. 2014. The economic psychology of incentives: An international study of top managers. Journal of World Business, 49(3): 350-361.

Prahalad, C. K. 2005. The fortune at the bottom of the pyramid: Eradicating poverty through profits. Upper Saddle River, NJ: Wharton School Publishing.

Putnam, R. D. 1995. Bowling Alone: America's Declining Social Capital. Journal of Democracy, 6(1): 65-78.

Ramarajan, L., \& Reid, E. 2013. Shattering the myth of separate worlds: Negotiating nonwork identities at work. Academy of Management Review, 38(4): 621-644.

Rogers, E. 1983. Diffusion of Innovation. London, New York: Free Press.

Rugraff, E., Sánchez-Ancochea, D., \& Sumner, A. (Eds.). 2009. Transnational corporations and development policy: critical perspectives. Houndmills, Basingstoke, Hampshire; New York: Palgrave Macmillan.

Saebi, T., Foss, N. J., \& Linder, S. 2019. Social Entrepreneurship Research: Past Achievements and Future Promises. Journal of Management, 45(1): 70-95.

Sarasvathy, S. D. 2001. Causation and effectuation: Toward a theoretical shift from economic inevitability to entrepreneurial contingency. Academy of Management Review, 26(2): 243263.

Schad, J., \& Bansal, P. 2018. Seeing the Forest and the Trees: How a Systems Perspective Informs Paradox Research. Journal of Management Studies, 55(8): 1490-1506.

Schwenke, C. 2009. Reclaiming value in international development: the moral dimensions of development policy and practice in poor countries. Westport, Conn: Praeger.

Sen, A. 2001. Development as freedom. New York: Oxford University Press.

Shane, S., \& Venkataraman, S. 2000. The promise of entrepreneurship as a field of research. Academy of Management Review, 25(1): 217-226.

Shweder, R. A., Much, N. C., Mahapatra, M., \& Park, L. 1997. The "Big Three" of Morality (Autonomy, Community, and Divinity), and the "Big Three" Explanations of Suffering. In A. Brandt \& P. Rozin (Eds.), Morality and Health. New York: Routledge.

Slade Shantz, A., Kistruck, G. M., Pacheco, D. F., \& Webb, J. W. 2019. How Formal and Informal Hierarchies Shape Conflict within Cooperatives: A Field Experiment in Ghana. Academy of Management Journal, (In Press).

Slade Shantz, A., Kistruck, G., \& Zietsma, C. 2018. The opportunity not taken: The occupational 
identity of entrepreneurs in contexts of poverty. Journal of Business Venturing, 33(3): 416-437.

Sörensen, J. S. (Ed.). 2010. Challenging the aid paradigm: Western currents and Asian alternatives. New York, Basingstoke, Hampshire: Palgrave Macmillan.

Spulber, D. F. 1996. Market Microstructure and Intermediation. Journal of Economic Perspectives, 10(3): 135-152.

Stryker, S., \& Burke, P. J. 2000. The Past, Present, and Future of an Identity Theory. Social Psychology Quarterly, 63(4): 284.

Sutter, C. J., Webb, J., Kistruck, G., Jr, D. J. K., \& Ireland, R. D. 2017. Transitioning entrepreneurs from informal to formal markets. Journal of Business Venturing.

Sutter, C. J., Webb, J. W., Kistruck, G. M., \& Bailey, A. V. G. 2013. Entrepreneurs' responses to semi-formal illegitimate institutional arrangements. Journal of Business Venturing, 28(6): 743-758.

Sutter, C., Kistruck, G., \& Morris, S. 2014. Adaptations to Knowledge Templates in Base-of-thePyramid Markets: The Role of Social Interaction. Strategic Entrepreneurship Journal, 8(4): 303-320.

Szulanski, G., \& Jensen, R. J. 2006. Presumptive adaptation and the effectiveness of knowledge transfer. Strategic Management Journal, 27(10): 937-957.

Torres-Rojo, J. M., Moreno-Sánchez, R., \& Amador-Callejas, J. 2019. Effect of capacity building in alleviating poverty and improving forest conservation in the communal forests of Mexico. World Development, 121: 108-122.

Vachani, S., \& Smith, N. C. 2008. Socially Responsible Distribution: Distribution Strategies for Reaching the Bottom of the Pyramid. California Management Review, 50(2): 52-84.

Veltmeyer, H. 2011. The Critical Development Studies Handbook: Tools for Change. University of Chicago Press.

Viswanathan, M. 2013. Subsistence Marketplaces. eBookPartnership.com.

Viswanathan, M., \& Rosa, J. A. 2007. Product and Market Development for Subsistence Marketplaces: Consumption and Entrepreneurship beyond Literacy and Resource Barriers. Advances in International Management. Emerald Group Publishing Limited.

Vo, T. T., \& Van, P. H. 2019. Can health insurance reduce household vulnerability? Evidence from Viet Nam. World Development, 124: 104645.

Walsh, J. P. 2015. Organization and management scholarship in and for Africa... and the world. Academy of Management Perspectives, 29(1): 1-6.

Webb, J. W., Kistruck, G. M., Ireland, R. D., \& Ketchen, Jr., D. J. 2010. The entrepreneurship process in base of the pyramid markets: The case of multinational enterprise/ nongovernment organization alliances. Entrepreneurship Theory and Practice, 34(3): 555581.

Webb, J. W., Tihanyi, L., Ireland, R. D., \& Sirmon, D. G. 2009. You say illegal, I say legitimate: Entrepreneurship in the informal economy. Academy of Management Review, 34(3): 492510.

Weber, L., Mayer, K. J., \& Macher, J. T. 2011. An Analysis of Extendibility and Early Termination Provisions: The Importance of Framing Duration Safeguards. Academy of Management Journal, 54(1): 182-202.

Weinstein, N., \& Ryan, R. M. 2010. When helping helps: Autonomous motivation for prosocial behavior and its influence on well-being for the helper and recipient. Journal of Personality and Social Psychology, 98(2): 222-244. 
Welter, F., Baker, T., \& Wirsching, K. 2019. Three waves and counting: the rising tide of contextualization in entrepreneurship research. Small Business Economics, 52(2): 319330.

Williamson, O. 1985. The economic institutions of capitalism: firms, markets, relational contracting. Free Press.

World Bank. 2018. Poverty Overview. http://www.worldbank.org/en/topic/poverty/overview.

Wright, P. M., Coff, R., \& Moliterno, T. P. 2014. Strategic human capital: Crossing the great divide. Journal of Management, 40(2): 353-370.

Yunus, M. (2010). Building social business - The new kind of capitalism that serves humanity's most pressing needs. New York: Public Affairs.

Zoogah, D.B., Peng, M.W. and Woldu, H., 2015. Institutions, resources, and organizational effectiveness in Africa. Academy of Management Perspectives, 29(1): 7-31. 


\title{
TABLES AND FIGURES
}

\author{
Table 1 \\ Theoretical relevance of selected contextual differences
}

\section{Contextual}

Difference

\author{
Description and Theoretical Relevance
}

\section{$\underline{\text { Micro level }}$}

Not profit maximizing, Satisficing

Shorttermism

Unfamiliarity with MarketThe behaviours and goals of those living in poverty are often directed towards saticficing, not profit maximization. (Kistruck et al., 2013) Ex. Relevance: That the goal of decision making is directed towards profit maximization is a foundation assumption in many literatures.

Based System

Scarcity, poverty, and other factors cause beneficiaries to have narrow temporal orientations. (Mullainathan \& Shafir, 2013) Ex. Relevance: Levels of short-termism fall outside the bounds normally considered in the literature.

The market-based system is relatively new, especially in rural areas, having become widespread only after the last wave of independence in the 1960s. (Meredith, 2011) Ex. Relevance: Familiarity endows actors with a tacit understanding of many market functions, which is the empirical background on which most theory is built.

Dependence on Heuristics

Due to unfamiliarity with markets, and limited human capital, heuristics guide decisionmaking. (Sutter et al., 2017) Ex. Relevance: The areas and ways in which heuristics are used in decision-making making diverge from those the literature currently considers.

Fatalism Beneficiaries often feel that they have little power over what happens to them, ascribing outcomes instead to religion, class, pre-existing power structures, or chance. (Branco, 2007) Ex. Relevance: Nature of decision-making fundamentally changes if one does not think their actions matter.

Limited Because development agencies 'do things' for them, beneficiaries often have little agency Agency

Risk-aversion over decision-making. (Banerjee and Duflo, 2011) Ex. Relevance: Nature of decision-making changes when one does not have agency over key portions.

Risk-aversion is common in poverty as minor deviations are highly problematic at subsistence levels. (Banerjee and Duflo, 2011)) Ex. Relevance: Levels of systematic riskaversion are much higher than explored in the literature, impacting the opportunities pursued and decisions made.

Entrenchment There is often little desire to change activities, because of fear of the unknown, and because of practices of the conforming pressure of institutions. (Viswanathan, 2013) Ex. Relevance: Behavioural flexibility assumed in the literature is undercut.

\section{$\underline{\text { Meso level }}$}

Desire for beneficiary value capture Unlike in traditional transaction set-ups, development organizations are fundamentally concerned with allowing beneficiaries to capture value. (Ansari, Munir, \& Gregg, 2012) Ex. Conservatism Relevance: This undercuts broad assumptions about the goals of transacting partners.

Traditional forces such as religion tend to constrain change, especially with respect to the role of women. (Mair et al., 2012) Ex. Relevance: Makes especially salient the role of repressive identities and power dynamics in identity formation and group dynamics. 
Traditional Institutions

Communal

Orientations

Overlapping

Soc. and

Econ. lives

Strong and

overlapping

SNs

\section{Macro level}

Institutional underdevelopment

Inadequate Infrastructure

Information

Scarcity

Resource

Scarcity

General instability

Static environments
Chieftaincies, trading circles, self-help groups, and women's groups are integral to daily life. (Amoako and Lyon, 2014) Ex. Relevance: This context is a microcosm for understanding how individuals/organizations manage to operate under institutional plurality.

Subsistence communities often have heightened communal orientations, leading to prosocial behaviours, and strong reciprocity. (Khayesi and George, 2011) Ex. Relevance: The assumed ego-centric nature of decision-making needs revisiting.

There is no clear-cut separation of social and economic lives. (Banerjee and Duflo, 2011) Ex. Relevance: Levels of overlap surpass that considered in the literature, complicating processes involving norms and social ties.

Social networks are the core structuring element of everyday life, including for economic activities. (Slade Shantz et al, 2018) Ex. Relevance: Many functions attributed to impersonal institutions instead reside in social networks, which are dynamic.

Core market institutions are missing: property rights are weak, and contract law is nonexistent outside small pockets of major cities. Informal, socially-held institutions predominate. (de Soto, 2000; George et al., 2016) Ex. Relevance: That institutions are informally held within social structures rather than universal infers fundamentally different mechanisms underpinning market exchange.

Widespread underdevelopment in electricity, roads, telecommunications, and sanitation. (Webb et al., 2010) Ex. Relevance: The cost of monitoring and enforcement are proportionally large enough to require reconsidering exchange structuring.

Information technology deficits, and the 'closed' nature of rural communities makes information scarce. ( Slade Shantz et al. 2019) Ex. Relevance: Nature of information flows fundamentally differs, challenging theories assuming broad information accessibility.

A lack of physical and financial resources is core to poverty. (Narayan and Petesch, 2002) Ex. Relevance: A lack of financial slack undercuts contracting forms and resource allocation strategies.

Exchange rate fluctuations, global commodity prices, political instability, and conflict make prices and supply chains unstable. (Bullough et al., 2014) Ex. Relevance: High levels of instability are usually only theorized in new or changing industries, rather than for an entire economy.

Indigenous innovation is limited, leading to broadly static markets and consumer preferences. (Viswanathan, 2013) Ex. Relevance: Many theories assume a background set of opportunities just waiting to be discovered. 
Table 2

Examples of How to Build Theory from the Context of Market Orchestration

\section{Contextual Market orchestration situation, theoretical lens and framing, research question, and Difference contribution}

1. Identification of new market opportunities \& Entrepreneurship Literature

Desire for Development organizations often identify opportunities for which they will lose money. beneficiary Theo. Frame: Theories of entrepreneurship hold that decision-making is predicated on value capture tolerance for risk as a central element. However, development organizations are fundamentally concerned about both their risk, as well as that of their beneficiaries. RQ: How does entrepreneurial decision-making change when a focal actor must consider risk tolerance levels for another party? Contribution: Addition of new explanators (how others' risk is assessed) and mechanisms for how these impact decision-making.

Communal After entrepreneur training, beneficiaries often pursue opportunities that show little profit orientation potential. Theo. Frame: Current theories of opportunities take an entrepreneur-centric approach, and frame decision-making as directed towards their benefit. However, communal orientations change this assumption, and might therefore require novel considerations of the relevant dimensions of an opportunity. RQ: Under a communal orientation, what makes an opportunity valuable? Contribution: New explanators for existing outcomes such as recognition and exploitation. New outcomes such as community benefit, and status implications.

Overlapping Beneficiaries often do not act after undertaking an entrepreneur training program; they do social and not start a business or change their current one. Theo. Frame: Resource drain theory view economic social and economic lives as having conflicting demands, yet drawing on the same finite lives pool of resources. This view suggests that inaction (failure of the program) may be because of social obligation. RQ: How do social obligations impact entrepreneurial performance? Contribution: New explanator (social obligations: such as marriages, weddings, children) for an existing DV (performance).

\section{Organizing groups \& Organizational behaviour literature on groups}

Communal Beneficiary groups struggle to stay focused on their purpose when the group starts being orientation used for broader communal purposes. E.g. letting in less productive farmers. Theo. Frame: Resource dependency theory suggests the group should cut social obligations so the group can maximize its performance. However, perhaps the group views success as helping the community. RQ: What does success mean for subsistence groups? Contribution: Unpacking a new dependent variable and suggesting new mechanisms for accomplishing this.

Communal Beneficiary groups struggle to stay focused on their purpose when the group starts being orientation used for broader communal purposes. E.g. letting in less productive farmers. Theo. Frame: Resource dependency theory suggests the group should cut social obligations so the group can maximize its performance. However, perhaps the group views success as helping the community. RQ: What does success mean for subsistence groups? Contribution: Unpacking a new dependent variable and suggesting new mechanisms for accomplishing this.

\section{Training in new practices \& Knowledge transfer literature grounded in psychology and sociology}

Dependence Getting beneficiaries to take up new practices - such as how to milk cows, or to create shea on heuristics soap - is perpetually problematic. Theo. Frame: Cognitive fit theory suggests that basing knowledge transfer on existing heuristics may be beneficial. Little is known of these 
heuristics though. RQ: What heuristics are employed for market decision-making? How can existing heuristics be used to build knowledge of new tasks? Contribution: New IVs (heuristics) are identified, new mechanisms are unpacked for how to redirect these to the market.

Strong and Social networks are relied upon for information. This is problematic when misinformation overlapping such as how to use antibiotics with one's chickens - is spread through them. Theo. Frame: social networks Attentional theories suggest that how we access information from social networks is a structural undertaking. So, existing social structures may direct attention, rather than those structures needed for a market activity. RQ: How do broader social ties direct attention to information for market-based activities? How can attention be redirected to appropriate sources? Contribution: Qualitative inquiry may uncover new relationships.

\section{Facilitating new transactional linkages \& Strategy literature on inter-organizational structuring}

Limited Agency

Historically, beneficiaries received charity from development organizations, so they expect things to be done for them. Theo. Frame: Imprinting theory suggests that early interactions have a strong influence on ongoing perceptions. However, imprinting theory focuses on routinized behaviour, not on the routinization of cognitive states. RQ: How long lasting is cognitive imprinting? How can routinized cognitive states be altered? Contribution: New outcomes: duration and breadth of cognitive imprinting. New mechanisms: overcoming cognitive imprinting.

Short- $\quad$ Beneficiaries frequently sell their crops to local intermediaries at a lower price than they termism would get from an agreed upon contract, as they want money immediately. Theo. Frame: Agency theory is broadly relevant, but inclusion of extreme temporal discounting undercuts assumptions. RQ: How does the duration (total, and between periods) of a contract interact with temporal orientations to impact outcomes? Contribution: New moderator of temporal orientation. New mechanisms for the interaction with contract duration.

Inadequate Managing value chains is perpetually problematic in the absence of good road networks. infrastructure Theo. Frame: Transaction cost economics suggests the need to develop a system minimizing costs. However, TCE assumes efficient infrastructure to support transactions, which allows for complex contracts. RQ: In the absence of efficient infrastructure, what are the cost tradeoffs between complex and simple contracts? Contribution: This context is far enough removed from traditional contexts that new relationships can be uncovered. For instance, will costs be minimized via complex and specialized governance systems (e.g. a large cooperative with specialized marketing and transportation arms), or by more autonomous and agile systems (e.g. many small cooperatives knowledgeable about local situation). Can inform the types of governance under TCE. 
Table 3

Additional Opportunities for Contributing to Management Theory

\footnotetext{
Theory/

Concept Level

Example

Agency Micro CD: Dependence on Heuristics. AC: Content of contracts is considered. TR: New

Theory explanator of degree of contract comprehension. New moderator or contracting familiarity. PR: Contract development for new contractees.

Meso CD: Strong and overlapping social networks. AC: Agent makes decisions based on own preferences. TR: New explanator of communal influence on agent behaviour. PR: Designing more effective contracts.

Macro CD: Resource Scarcity. AC: Availability of money as a motivator. TR: New explanators, as the lack of money means the usual financial structuring elements are severely limited. PR: Doing development under financial constraints.

Transaction Micro CD: Dependence on Heuristics. AC: Transactions are structured on price signals. TR: Cost New explanators, as the enacted heuristics drive transaction structure. PR: Knowing what Economics

Meso CD: Conservatism. AC: Transactions structured on price signals. TR: Cultural discrimination against women (new explanator) may prevent efficient transaction structuring. PR: Knowing what discrimination needs to be overcome.

Macro CD: Inadequate Infrastructure. AC: Relative stability of transaction costs. TR: Unreliable infrastructure (new explanator) makes transaction costs variable, possibly leading to new transaction structures (outcome). PR: Designing governance structures.

Inst'l Theory Micro CD: Not profit maximizing, Satisficing. AC: Economic institutions are directed towards (economic) economic efficiency. TR: New institutional orientations, as norms may be directed towards other ends, such as fairness. PR: Aligning interventions with norms.

Meso CD: Traditional Institutions. AC: Pre-eminence of formal contract enforcement mechanisms. TR: New relationships, as economic activity embedded in chieftaincies are malleable, and enforcement may be driven by other considerations. PR: Building enforceable interventions.

Macro CD: Information scarcity. AC: Efficiency of market institutions is undercut when information is inaccessible. TR: New moderator when exploring relationship between de jure institutions and economic outcomes. PR: Identifying information bottlenecks.

Inst'l Theory Micro CD: Dependence on Heuristics. AC: Internalizability of new sets of external norms. TR: (sociological) New mediator: conflict between market norms and existing heuristics. PR: Better introduction of markets.

Meso CD: Traditional Institutions. AC: Relative inter- and intra-community variability. TR: New relationships can be unearthed through studying the highly localized nature and impact of norms from different institutions. PR: Customizing interventions to communities.

Macro CD: General instability. AC: That institutions are slow to change. TR: New mechanisms for explaining the rapid uptake of norms may be found. New moderator related to historically salient instability and change. PR: Driving institutional change.
} 
Stakeholder Micro CD: Unfamiliarity with Market-Based System. AC: Salience is based on power, Theory legitimacy, and urgency. TR: New moderator, as unfamiliarity may cause the overlooking of otherwise key stakeholders. PR: Helping entrepreneurs identify key constituents.

Meso CD: Overlapping Social and Economic lives. AC: Focal venture is reference for stakeholder salience TR: New explanator as connections outside economic sphere (e.g. communal hierarchy) may impact salience. PR: Understanding who key stakeholders are.

Macro CD: General instability. AC: Stakeholder salience and importance is stable. TR: New moderator for understanding which stakeholders are salient, and new explanators for why. PR: Identifying key stakeholders to interact with.

Resource- Micro CD: Entrenchment of practices. AC: New and valuable resources are leveraged. TR:

Based

Theory New explanator, as entrenchment may explain why valuable resources are not acted on. PR: How to get these resources used.

Meso CD: Communal Orientation. AC: SCA as desired outcome. TR: New relationships, as alternative outcomes such as communal performance or well-being may alter the relevant characteristics of resources, and the outcomes pursued. PR: Providing resources to fit communal preferences.

Macro CD: Resource Scarcity. AC: Theory generally assumes that wide variety of resources are available. TR: New mediating mechanisms between existing IVs and DVs. For instance, under resource constraints, it may no longer matter if a resource is imitable. PR: Identifying valuable resources in a community.:

Entrepreneur Micro CD: Fatalism. AC: Novel opportunities are sought after and continued. TR: New -ial explanators for the empirical fact that levels of venture imitation are very high. PR:

Opportunities

Meso CD: Communal Orientation. AC: Opportunities are assessed with reference to focal entrepreneur. TR: New moderator of enactment decisions, as communal orientations may impact decision-making. PR: Teaching entrepreneurship in a way that matches beneficiary approaches.

Macro CD: Institutional underdevelopment. AC: Property rights are present. TR: Novel processes for enacting an opportunity, in order to overcome lack of property rights. PR: Refining these exploitation efforts. 


\section{Figure 1}

\section{A Framework for Developing Theory from Market Orchestration}

Conceptual Overview of Process

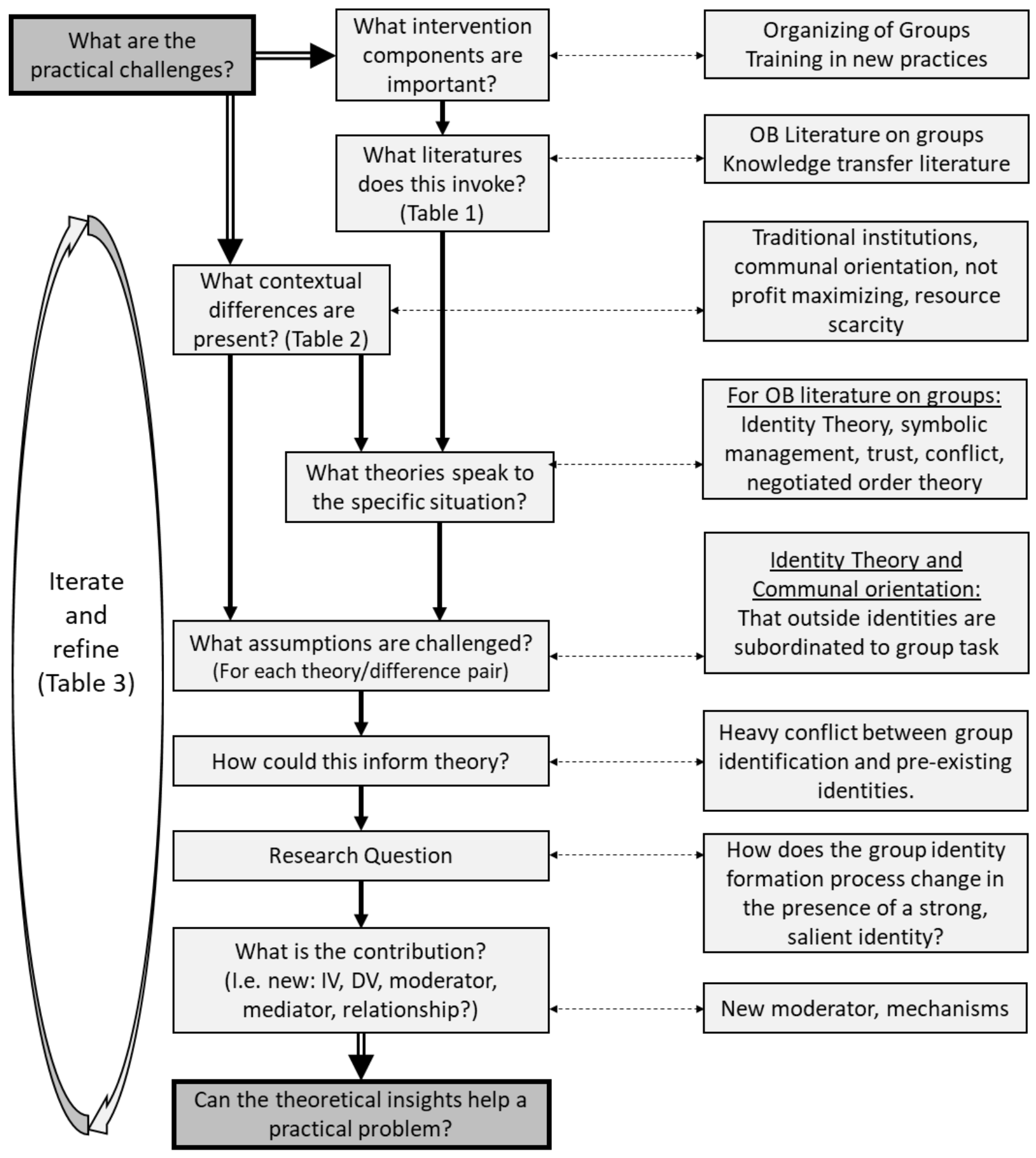

\section{Example: Village Savings and \\ Loan Association
Loand}

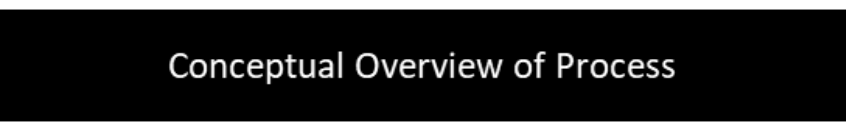

